\title{
Novel Seimatosporium Species from Grapevine in Northern California and Their Interactions with Fungal Pathogens Involved in the Trunk-Disease Complex
}

\author{
Daniel P. Lawrence and Renaud Travadon, Department of Plant Pathology, University of California, Davis 95616; and Kendra \\ Baumgartner, ${ }^{\dagger}$ United States Department of Agriculture-Agricultural Research Service, Crops Pathology and Genetics Research Unit, Davis, \\ CA 95616
}

\begin{abstract}
Seimatosporium spp. and closely related "pestalotioid fungi" have been isolated from vineyards worldwide, but their ecological status in grapevine wood is unclear. To determine their involvement in the grapevine trunkdisease complex, we tested the pathogenicity of Californian isolates obtained from vines with general symptoms of Botryosphaeria, Eutypa, and Phomopsis diebacks. Multilocus phylogenetic analyses revealed three species: Seimatosporium vitis and two newly described and typified species, $S$. luteosporum sp. nov. and $S$. vitifusiforme sp. nov. Inoculations to woody stems of potted grapevines of both isolates of $S$. vitis and one isolate of $S$. vitifusiforme, but not $S$. luteosporum, were associated with significantly

larger lesions than those of noninoculated controls. Coinoculations with trunk pathogens (Cryptovalsa ampelina, Diaporthe ambigua, Diatrypella verruciformis, Diplodia seriata, and Eutypa lata), coisolated from the same wood cankers in the field, brought about increased lesion lengths for $S$. vitifusiforme paired with D. seriata, and S. luteosporum paired with Diaporthe ambigua. In contrast, there were no differences in lesion lengths of $S$. vitis and Diatrypella verruciformis or S. vitis and E. lata, inoculated alone or together. Our findings suggest that Seimatosporium spp. are involved in the grapevine trunk-disease complex, and their virulence may depend on or affect that of trunk pathogens.
\end{abstract}

Grapevine trunk diseases are among the main depreciable drivers of vineyard longevity and productivity worldwide. The grape industry suffers large economic losses due to cumulative yield losses and limited profitable lifespans (Kaplan et al. 2016), premature replanting of vineyards (Sipiora and Cuellar 2014), and impacts on wine quality (Lorrain et al. 2012). Trunk diseases are caused by a diverse community of fungal pathogens (Bruez et al. 2016; Travadon et al. 2016), which compromise the permanent woody structure of the vine through the combined actions of cell-wall-degrading enzymes and secreted toxins (Massonnet et al. 2018; Morales-Cruz et al. 2015). The collective impact of the mixed infections on symptom expression are determined, in part, by the diverse virulence factors among trunk pathogens, the expression of which varies depending on fungal species composition (Morales-Cruz et al. 2018). Beyond identifying the species composition of mixed infections, it is critical to characterize the fungal interactions, which can impact wood colonization and disease development (Boddy and Hiscox 2016).

Several "pestalotioid fungi" belonging to the family Sporocadaceae (within the class Sordariomycetes) (Jaklitsch et al. 2016) have been reported as components of the grapevine trunk-disease complex: Neopestalotiopsis Maharachch., K. D. Hyde \& Crous, Pestalotiopsis Steyaert, Seimatosporium Corda, and Truncatella Steyaert

${ }^{\dagger}$ Corresponding author: K. Baumgartner;

E-mail: Kendra.Baumgartner@ars.usda.gov

Funding: This research was funded by grant 2012-51181-19954 to K. Baumgartner and R. Travadon from the United States Department of Agriculture-National Institute of Food and Agriculture's Specialty Crop Research Initiative program.

Mention of trade names or commercial products is solely for the purpose of providing specific information and does not imply recommendation or endorsement by the U. S. Department of Agriculture. USDA is an equal opportunity provider and employer.

*The $\boldsymbol{e}$-Xtra logo stands for "electronic extra" and indicates that two supplementary figures are published online.

Accepted for publication 7 December 2017.

This article is in the public domain and not copyrightable. It may be freely reprinted with customary crediting of the source. The American Phytopathological Society, 2018.
(Arzanlou et al. 2013; Jayawardena et al. 2015; Maharachchikumbura et al. 2017; Úrbez-Torres et al. 2009). They are named pestalotioid fungi because their anamorphic state produces conidia that are multiseptate and more-or-less fusiform, with apical or basal appendages (Maharachchikumbura et al. 2014). Generic boundaries based on morphology are easily confused, due to intermediate conidial morphologies of closely related genera. Of the three Seimatosporium spp. (Seimatosporium botan Sat. Hatak. \& Y. Harada, S. vitis Y. P. Xiao, Camporesi \& K. D. Hyde, and S. hysterioides (Fuckel) Brockmann) reported from grapevines in Chile, Hungary, Italy, Iran, and Australia (Díaz et al. 2012; Mehrabi et al. 2017; Senanayake et al. 2015; Sergeeva et al. 2005; Váczy 2017), only S. botan has been evaluated in standard pathogenicity tests on trunks and canes of field vines (Díaz et al. 2012). S. vitis colonization was evaluated on green shoots and detached canes but this is not conclusive evidence of its pathogenicity to woody stems of intact plants, which are the types of tissues this species was originally isolated from in the field (Díaz et al. 2012; Váczy 2017).

The genus Seimatosporium was erected with $S$. rosae Corda as the type species and consists predominately of saprobes and endophytes of woody plants (Goonasekara et al. 2016; Norphanphoun et al. 2015; Perera et al. 2016; Wijayawardene et al. 2016), although some species are pathogens (e.g., Leaf spot of eucalypts) (Barber et al. 2011). The genus is characterized by producing holoblastic or annelidic conidiogenous cells within acervuli or pycnidia that produce multiseptate conidia with pigmented median cells, a truncate basal cell with or without an eccentrically positioned appendage, and with or without a centrally positioned unbranched apical appendage (Nag Raj 1993). Seimatosporium spp. are heteromorphic, with species producing divergent conidial shapes. For example, conidia can vary from fusiform (S. rosae) to obovoid (S. vitis) to acerose (S. biseptatum (H. J. Swart \& M. A. Will.) P. J. Barber \& Crous). Septation can vary from 2 to 3 to 5 septa with continuous or occasional septal constrictions, and with or without an apical or basal appendage (Barber et al. 2011), thus making species-level assignment challenging.

From symptomatic vines in northern California vineyards, we isolated multiple isolates with morphological characteristics of Seimatosporium spp. along with several causal fungi of the following trunk diseases: Botryosphaeria dieback (Diplodia seriata De Not.) (Úrbez-Torres and Gubler 2009), Eutypa dieback (Cryptovalsa ampelina (Nitschke) Fuckel, Diatrypella verruciformis (Ehrh.) Nitschke, and Eutypa lata (Pers.) Tul. \& C. Tul.) (Trouillas et al. 2010), and Phomopsis dieback (Diaporthe ambigua Nitschke) (Lawrence et al. 2015). These fungal 
species can theoretically exhibit antagonistic, neutral, or synergistic interactions while exploiting the same resource (Begon et al. 2006). Antagonism (negative effects on each other's development) may occur through competition for nutrients or space, toxin production, or induced host resistance. Species that are antagonistic would, furthermore, rarely cooccur. In contrast, synergism (promotion of each other's development) would be supported by frequent cooccurrence from the same ecological niche. Because of our frequent isolations from wood cankers of both Seimatosporium spp. and trunk pathogens, we tested the hypothesis that these fungal species are synergistic. Our objectives were to (i) characterize the diversity of Seimatosporium spp. associated with symptoms of trunk diseases, based on morphological and molecular analyses, and pathogenicity testing, and (ii) evaluate in vitro and in planta interactions between Seimatosporium spp. and trunk pathogens isolated from the same wood cankers.

\section{Materials and Methods}

Grapevine sampling and fungal isolation. Isolates originated from two winegrape vineyards in Napa and Solano Counties of northern California (Table 1), which were surveyed and sampled for trunk-disease pathogens (Travadon and Baumgartner 2015).
Wood samples were collected from mature grapevines ( $>10$ years old) with dead spurs, dead cordons, and dead canes, which are symptoms shared by the dieback-type trunk diseases (Botryosphaeria, Eutypa, and Phomopsis diebacks). Fungi were isolated from wood cankers (Fig. 1A to D) following the detailed protocol of Baumgartner et al. (2013). Isolation plates were incubated at $25^{\circ} \mathrm{C}$ in darkness for up to 21 days. Fungal colonies that exhibited typical Seimatosporium characteristics (namely, a white or pale yellow, cottony morphology with a mostly smooth margin) were subcultured to potato dextrose agar (PDA) and incubated in darkness for 7 days. Fungi that exhibited cultural characteristics of other known grapevine trunk pathogens-members of the families Botryosphaeriaceae (fast-growing colony, which darkens with age), Diaporthaceae (medium-growing colony with a shiny, reflective margin), and Diatrypaceae (medium-growing white colony with a whirled margin) — were also subcultured. In this way, in total, 25 Seimatosporium isolates and 15 trunk pathogen isolates were hyphal-tip purified to fresh PDA plates for molecular and morphological characterization.

Phylogenetic analyses. Total genomic DNA was isolated from mycelium (scraped with a sterile scalpel from the surface of a 14-dayold culture) using the DNeasy Plant kit (Qiagen, Valencia, CA), following

Table 1. Seimatosporium isolates and those of taxonomically related genera isolated from grapevine and other woody hosts ${ }^{\mathrm{a}}$

\begin{tabular}{|c|c|c|c|c|c|c|c|}
\hline \multirow[b]{2}{*}{ Species } & \multirow[b]{2}{*}{ Isolate $^{c}$} & \multirow[b]{2}{*}{ Geographic origin } & \multirow[b]{2}{*}{ Host } & \multicolumn{4}{|c|}{ GenBank accession ${ }^{b}$} \\
\hline & & & & ITS & LSU & BT & TEF1- $\alpha$ \\
\hline Adisciso yakushimense & NBRC $104194^{\mathbf{T}}$ & Japan & Symplocos prunifolia & AB594789 & AB593721 & $\ldots$ & $\ldots$ \\
\hline Cryptovalsa ampelina & Wint015 & Solano County, CA & Vitis vinifera & KY849963 & $\ldots$ & $\ldots$ & \\
\hline Diaporthe ambigua & Wint904 & Solano County, CA & V. vinifera & KM669923 & $\ldots$ & $\ldots$ & KM669779 \\
\hline Diatrypella verruciformis & Napa016 & Napa County, CA & $V$. vinifera & KY849964 & $\ldots$ & $\ldots$ & $\ldots$ \\
\hline Diplodia seriata & Napa810 & Napa County, CA & V. vinifera & KY849966 & $\ldots$ & $\ldots$ & $\ldots$ \\
\hline Discostroma fuscellum & NBRC 32625 & Unknown & Rosa canina & AB594794 & AB593726 & $\ldots$ & $\ldots$ \\
\hline D. stoneae & NBRC $32690^{\mathbf{T}}$ & Unknown & Unknown & AB594797 & AB593729 & $\ldots$ & $\ldots$ \\
\hline D. tostum & TC2-029 ${ }^{\mathbf{T}}$ & Unknown & Unknown & AB594795 & AB593727 & $\ldots$ & $\ldots$ \\
\hline Eutypa lata & Napa003 & Napa County, CA & V. vinifera & KY849965 & $\ldots$ & $\ldots$ & $\ldots$ \\
\hline Immersidiscosia eucalypti & NBRC 104195 & Japan & Quercus myrsinifolia & AB594790 & AB593722 & $\ldots$ & $\ldots$ \\
\hline I. eucalypti & NBRC 104196 & Japan & Q. myrsinifolia & AB594791 & AB593723 & $\ldots$ & $\ldots$ \\
\hline I. eucalypti & NBRC 104197 & Japan & Ardisia japonica & AB594792 & AB593724 & $\ldots$ & $\ldots$ \\
\hline I. eucalypti & NBRC 242781 & Japan & Decayed leaves & AB594793 & AB593725 & $\ldots$ & $\ldots$ \\
\hline Sarcostroma lomatiae & CBS 118144 & South Africa & Restio sp. & DQ278921 & DQ278926 & $\ldots$ & $\ldots$ \\
\hline Seimatosporium biseptatum & CPC 13584 & $\begin{array}{l}\text { New South Wales, } \\
\text { Australia }\end{array}$ & Eucalyptus cypellocarpa & JN871199 & JN871208 & $\ldots$ & $\ldots$ \\
\hline S. botan & HHUF $27946^{\mathbf{T}}$ & Japan & Paeonia suffruticosa & AB594799 & AB593731 & $\ldots$ & $\ldots$ \\
\hline S. botan & HMUC-sei-302PD & Chile & V. vinifera & JN088482 & $\ldots$ & $\ldots$ & $\ldots$ \\
\hline S. cornii & MFLUCC 14-0467 T & Italy & Cornus sp. & KT162918 & KR559739 & $\cdots$ & $\cdots$ \\
\hline S. discosioides & NBRC 104201 & Japan & Punica granatum & AB594800 & AB593732 & $\ldots$ & $\ldots$ \\
\hline S. elegans & NBRC 32674 & Japan & Melaleuca ericifolia & AB594801 & AB593733 & $\ldots$ & $\ldots$ \\
\hline S. eucalypti & СРC 156 & South Africa & E. smithii & JN871200 & JN871209 & $\ldots$ & $\ldots$ \\
\hline S. falcatum & СРC 13578 & $\begin{array}{l}\text { New South Wales, } \\
\text { Australia }\end{array}$ & Eucalyptus sp. & JN871204 & JN871213 & $\ldots$ & $\ldots$ \\
\hline S. ficeae & MFLUCC $15-0519^{\mathbf{T}}$ & Italy & Rubus sp. & KR092800 & KR920686 & $\ldots$ & $\ldots$ \\
\hline S. foliicola & NBRC 32676 & Japan & Juniperus phoenicea & AB594802 & AB593734 & $\ldots$ & $\ldots$ \\
\hline S. glandigenum & NBRC 32677 & Japan & Fagus sylvatica & AB594803 & AB593735 & $\ldots$ & $\ldots$ \\
\hline S. grevilleae & ICMP 10981 & South Africa & Protea sp. & AF405304 & AF382372 & $\ldots$ & $\ldots$ \\
\hline S. hakeae & NBRC 32678 & Japan & Pteridium aquilinum & AB594804 & AB593736 & $\cdots$ & $\cdots$ \\
\hline S. hypericinum & NBRC 32647 & Japan & Hypericum sp. & AB594805 & AB593737 & $\ldots$ & $\ldots$ \\
\hline S. lichenicola & NBRC 32680 & Japan & Ribes sp. & AB594806 & AB593739 & $\ldots$ & $\ldots$ \\
\hline S. lichenicola & MFLUCC 14-0052 & Italy & Rosa canina & KT005515 & KT005514 & $\cdots$ & $\cdots$ \\
\hline S. luteosporum & Napa754 & Napa County, CA & Prunus persica & KY706283 & KY706308 & KY706258 & KY706333 \\
\hline S. luteosporum & $\begin{array}{c}\text { Wint754/CBS } \\
142599^{T^{*}}\end{array}$ & Solano County, CA & V. vinifera & KY706284 & KY706309 & KY706259 & KY706334 \\
\hline S. mariae & NBRC 32681 & Japan & Correa reflexa & AB594807 & AB593740 & $\ldots$ & $\ldots$ \\
\hline S. obtusum & CPC $12935^{\mathbf{T}}$ & $\begin{array}{l}\text { New South Wales, } \\
\text { Australia }\end{array}$ & Corymbia henryi & JN871206 & JN871215 & $\cdots$ & $\ldots$ \\
\hline S. parasiticum & NBRC 32682 & Japan & Physocarpus amurensis & AB594808 & AB593741 & $\ldots$ & $\ldots$ \\
\hline
\end{tabular}

\footnotetext{
${ }^{a}$ GenBank accession numbers for sequences of four loci-ribosomal DNA (rDNA) internal transcribed spacer region (ITS), rDNA large subunit (LSU), nuclear locus $\beta$-tubulin (BT), and translation elongation factor 1- $\alpha$ (TEF1- $\alpha$ ) —were generated by this study (in bold) or from other studies.

$\mathrm{b}$ Sequences from isolates in our collection are highlighted in bold.

${ }^{\mathrm{c}} \mathrm{T}=$ type cultures and $*$ indicates isolates used for morphological characterization and pathogenicity assays.
} 
the manufacturer's instructions. Ribosomal DNA (rDNA) fragments, including the intervening internal transcribed spacer (ITS) regions and 5.8S rDNA, were amplified using primers ITS1 and ITS4 (White et al. 1990). Three additional loci were amplified for all Seimatosporium isolates. Amplification of ribosomal large subunit fragments (LSU) utilized primers LR0R (Rehner and Samuels 1994) and UnLo28S1220 (Bala et al. 2010), with the following polymerase chain reaction (PCR) program: initial denaturation $\left(94^{\circ} \mathrm{C}, 4 \mathrm{~min}\right)$; followed by 35 cycles of denaturation $\left(94^{\circ} \mathrm{C}, 60 \mathrm{~s}\right)$, annealing $\left(55^{\circ} \mathrm{C}, 30 \mathrm{~s}\right)$, and extension $\left(72^{\circ} \mathrm{C}, 120 \mathrm{~s}\right)$; and a final extension $\left(72^{\circ} \mathrm{C}, 10 \mathrm{~min}\right)$. Amplification of translation elongation factor $1-\alpha(\mathrm{TEF} 1-\alpha)$ fragments utilized primers EF1-728F and EF1-986R (Carbone and Kohn 1999), and amplification of the $\beta$-tubulin (BT) locus utilized primers T1 (O'Donnell and Cigelnik 1997) and Bt2b (Glass and Donaldson 1995), both with the following PCR program: initial denaturation $\left(95^{\circ} \mathrm{C}, 5 \mathrm{~min}\right)$; followed by 35 cycles of denaturation $\left(95^{\circ} \mathrm{C}, 30 \mathrm{~s}\right)$, annealing $\left(57^{\circ} \mathrm{C}, 30 \mathrm{~s}\right)$, and extension $\left(72^{\circ} \mathrm{C}, 60 \mathrm{~s}\right)$; and a final extension $\left(72^{\circ} \mathrm{C}, 10 \mathrm{~min}\right)$. PCR products were visualized on a $1.5 \%$ agarose gel ( $120 \mathrm{~V}$ for $25 \mathrm{~min})$ to validate presence and size of amplicons, purified via Exonuclease I and recombinant Shrimp Alkaline Phosphatase (Affymetrix, Santa Clara, CA), and sequenced in both directions on an ABI 3730 Capillary Electrophoresis Genetic Analyzer (College of Biological Sciences Sequencing Facility, University of California, Davis).

Forward and reverse nucleotide sequences were assembled, proofread, and edited in Sequencher (v. 5; Gene Codes Corporation, Ann Arbor, MI) and deposited in GenBank (Table 1). Isolates morphologically resembling trunk pathogens (i.e., species belonging to the families Botryosphaeriaceae, Diaporthaceae, and Diatrypaceae) were identified via BLASTn searches of the curated molecular repository for species identification of grapevine trunk pathogens, TrunkDiseaseID.org (Lawrence et al. 2017). BLASTn searches of the National Center for Biotechnology Information and extensive literature review (cited within) resulted in the collection of 51 ITS sequences with high similarity from type and nontype Seimatosporium isolates $(n=11$ and 40, respectively), which were included in our analyses for phylogenetic reference. Multiple sequence alignments were performed in MEGA v. 6 (Tamura et al. 2013) and manually adjusted where necessary in Mesquite v. 3.10 (Maddison and Maddison 2016). Alignments were submitted to TreeBASE under accession number S20203.

The datasets were analyzed using two different optimality search criteria, maximum-likelihood (ML) and maximum-parsimony (MP), in MEGA v. 6 (Tamura et al. 2013). For ML analyses, MEGA was used to infer a model of nucleotide substitution for each dataset, using the Akaike Information Criterion (AIC). Each ML analysis utilized the nearest-neighbor-interchange heuristic method and branch stability was determined by 1,000 bootstrap replicates. For MP analyses, heuristic searches with 1,000 random sequence additions were implemented with the tree-bisection-reconnection algorithm, with gaps treated as missing data. Bootstrap analyses with 1,000 replicates were used to estimate clade support. The following outgroups closely related to Seimatosporium sensu lato were selected based on previous phylogenetic analyses (Tanaka et al. 2011; Watanabe et al. 2016):

Table 1. (Continued from previous page)

\begin{tabular}{|c|c|c|c|c|c|c|c|}
\hline \multirow[b]{2}{*}{ Species } & \multirow[b]{2}{*}{ Isolate $^{c}$} & \multirow[b]{2}{*}{ Geographic origin } & \multirow[b]{2}{*}{ Host } & \multicolumn{4}{|c|}{ GenBank accession $^{b}$} \\
\hline & & & & ITS & LSU & BT & TEF1- $\alpha$ \\
\hline S. pezizoides & $71 \mathrm{~TB}$ & Unknown & Unknown & KF573991 & & 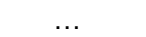 & $\ldots$ \\
\hline S. physocarpi & MFLUCC 14-0625 & Russia & P. opulifolius & KT198722 & KT198723 & $\ldots$ & $\ldots$ \\
\hline S. pistaciae & CBS $138865^{\mathbf{T}}$ & Iran & Pistacia vera & KP004463 & KР004491 & $\ldots$ & $\ldots$ \\
\hline S. pseudorosarum & MFLUCC 14-0466 & Italy & Rosa canina & KT284775 & KT281912 & $\ldots$ & $\ldots$ \\
\hline S. quercina & MFLUCC 14-1198 & Germany & Q. robur & KU974965 & KU974964 & $\ldots$ & $\ldots$ \\
\hline S. restionis & CBS 118154 & South Africa & Restio filiformis & DQ278922 & DQ278924 & $\ldots$ & $\ldots$ \\
\hline S. rhombisporium & MFLUCC 15-0727 & Italy & Vaccinium myrtillus & KR092792 & KR092780 & $\ldots$ & $\ldots$ \\
\hline S. rosae & MFLUCC 14-0621 ${ }^{\mathbf{T}}$ & Czechoslovakia & Rosa canina & KT198726 & KT198727 & $\ldots$ & $\cdots$ \\
\hline S. sorbi & MFLUCC 14-0469 & Italy & Sorbus torminalis & KT284774 & KT281911 & $\ldots$ & $\cdots$ \\
\hline $\begin{array}{l}\text { Seimatosporium } \\
\text { vitifusiforme }\end{array}$ & $\begin{array}{l}\text { Wint } 753 / \mathrm{CBS} \\
142600^{\mathbf{T}}\end{array}$ & Solano County, CA & Vitis vinifera & KY706296 & KY706321 & KY706271 & KY706346 \\
\hline S. vitifusiforme & Napa751 & Napa County, CA & $V$. vinifera & KY706289 & KY706314 & KY706264 & KY706339 \\
\hline S. vitifusiforme & Napa767 & Napa County, CA & $V$. vinifera & KY706290 & KY706315 & KY706265 & KY706340 \\
\hline S. vitifusiforme & Napa768* & Napa County, CA & $V$. vinifera & KY706285 & KY706310 & KY706260 & KY706335 \\
\hline S. vitifusiforme & Napa780 & Napa County, CA & $V$. vinifera & KY706286 & KY706311 & KY706261 & KY706336 \\
\hline S. vitifusiforme & Napa783 & Napa County, CA & $V$. vinifera & KY706291 & KY706316 & KY706266 & KY706341 \\
\hline S. vitifusiforme & Napa785 & Napa County, CA & $V$. vinifera & KY706292 & KY706317 & KY706267 & KY706342 \\
\hline S. vitifusiforme & Napa786 & Napa County, CA & $V$. vinifera & KY706293 & KY706318 & KY706268 & KY706343 \\
\hline S. vitifusiforme & Napa795 & Napa County, CA & $V$. vinifera & KY706294 & KY706319 & KY706269 & KY706344 \\
\hline S. vitifusiforme & Napa796 & Napa County, CA & $V$. vinifera & KY706287 & KY706312 & KY706262 & KY706337 \\
\hline S. vitifusiforme & Napa797 & Napa County, CA & $V$. vinifera & KY706288 & KY706313 & KY706263 & KY706338 \\
\hline S. vitifusiforme & Wint755 & Solano County, CA & $V$. vinifera & KY706297 & KY706322 & KY706272 & KY706347 \\
\hline S. vitifusiforme & Napa798 & Napa County, CA & $V$. vinifera & KY706295 & KY706320 & KY706270 & KY706345 \\
\hline S. vitis & MFLUCC 14-0051 ${ }^{\mathbf{T}}$ & Italy & $V$. vinifera & KR920363 & KR920362 & $\ldots$ & $\ldots$ \\
\hline S. vitis & Napa759 & Napa County, CA & $V$. vinifera & KY706282 & KY706307 & KY706257 & KY706332 \\
\hline S. vitis & Napa764 & Napa County, CA & $V$. vinifera & KY706273 & KY706298 & KY706248 & KY706323 \\
\hline S. vitis & Napa772 & Napa County, CA & $V$. vinifera & KY706275 & KY706300 & KY706250 & KY706325 \\
\hline S. vitis & Napa774* & Napa County, CA & $V$. vinifera & KY706276 & KY706301 & KY706251 & KY706326 \\
\hline S. vitis & Napa776 & Napa County, CA & $V$. vinifera & KY706277 & KY706302 & KY706252 & KY706327 \\
\hline S. vitis & Napa779 & Napa County, CA & $V$. vinifera & KY706274 & KY706299 & KY706249 & KY706324 \\
\hline S. vitis & Napa781 & Napa County, CA & $V$. vinifera & KY706280 & KY706305 & KY706255 & KY706330 \\
\hline S. vitis & Napa782* & Napa County, CA & $V$. vinifera & KY706278 & KY706303 & KY706253 & KY706328 \\
\hline S. vitis & Napa784 & Napa County, CA & $V$. vinifera & KY706281 & KY706306 & KY706256 & KY706331 \\
\hline S. vitis & Wint752 & Solano County, CA & $V$. vinifera & KY706279 & KY706304 & KY706254 & KY706329 \\
\hline S. walkeri & СРC 17644 & Australia Victoria & Eucalyptus sp. & JN871207 & JN871216 & $\cdots$ & $\cdots$ \\
\hline $\begin{array}{l}\text { Synnemapestaloides } \\
\text { rhododendri }\end{array}$ & MAFF $239201^{\mathbf{T}}$ & Japan & $\begin{array}{r}\text { Rhododenderon } \\
\text { brachycarpum }\end{array}$ & LC047753 & LC047744 & $\cdots$ & $\cdots$ \\
\hline S. rhododendri & TAMA 492 & Japan & R. brachycarpum & LC047760 & LC047749 & $\cdots$ & $\cdots$ \\
\hline
\end{tabular}


Sarcostroma lomatiae (McAlpine) Nag Raj CBS 118144, Seimatosporium ficeae Dayar., Phook. \& K. D. Hyde MFLUCC 15-0519 and Seimatosporium rhombisporum Senan., Camporesi \& K. D. Hyde MFLUCC 15-0727 (ITS and ITS + LSU analyses), and Synnemapestaloides foliicola (Berk.) Kyoko Wanta., Nozawa, Kaz. Tanaka \& Toy. Sato isolate NBRC 32676 (ITS + LSU + TEF1- $\alpha$ + BT analysis).

Morphology. Mycelial plugs ( $5 \mathrm{~mm}$ in diameter) were taken from the margin of an actively growing culture and transferred to 90-mmdiameter Petri dishes. Radial growth was measured after 14 days at $25^{\circ} \mathrm{C}$ in darkness for triplicate plates per isolate by taking two colony diameter measurements perpendicular to each other. Assessments of colony color (Rayner 1970) and morphology were made at 14 days. To induce fruiting bodies, a subset of Seimatosporium isolates representing different species (Napa768, Wint753, Wint754, Napa774, and Napa782), based on preliminary phylogenetic analyses were inoculated on grapevine wood segments embedded in PDA. Briefly, 1-year-old grapevine canes (approximately $1 \mathrm{~cm}$ in diameter) were collected in the vineyard, cut to 5-cm segments, and autoclaved twice (autoclaving $24 \mathrm{~h}$ apart, both times at $122^{\circ} \mathrm{C}$ for $25 \mathrm{~min}$ ). Autoclaved segments were then placed in 90-mm Petri dishes (two to three segments per dish) and PDA was poured to embed them. A mycelial plug from an actively growing culture was placed on the surface of the agar, between the wood segments. Petri dishes were incubated at room temperature under a natural photoperiod in December 2016, and fruiting body formation was monitored weekly for 4 weeks.

Fruiting bodies ( $n=30$ per isolate) were characterized in terms of structure and size. Fresh fruiting bodies were transversely sectioned by hand with a razor blade and observed at $\times 100$ (Leica DM500B; Leica Microsystems CMS GmbH, Wetzlar, Germany). No stain was applied, to preserve the natural pigments. Conidial dimensions $(n=$ 50 per isolate) were measured at $\times 100$ from 28 -day-old cultures (squash mounts in sterile deionized water). Analyses of variance (ANOVA) were used to test the null hypotheses that colony diameters and conidial dimensions were similar among isolates. Homogeneity of variance was evaluated prior to ANOVA. ANOVA was performed using the MIXED procedure in SAS (v. 9.2; SAS Institute, Cary, NC), and the main effect of isolate was treated as a fixed effect. For significant effects $(P<0.05)$, means were compared by Tukey's tests.
Fungal interactions in planta. Dual inoculations to the woody stems of potted grapevines were used to evaluate whether Seimatosporium isolates were antagonistic or synergistic with trunk pathogens, based on smaller or larger lesions, respectively, when paired versus alone. Pairs of isolates originating from the same wood cankers in the field were coinoculated (listed in order of Seimatosporium isolate and trunk-pathogen isolate): Seimatosporium vitifusiforme Wint753 and C. ampelina Wint015, S. luteosporum Wint754 and D. ambigua Wint904, S. vitifusiforme Napa768 and Diplodia seriata Napa810, S. vitis Napa774 and E. lata Napa003, and S. vitis Napa782 and Diatrypella verruciformis Napa016 (Table 1). Inoculations of individual Seimatosporium isolates served as pathogenicity tests for our newly described species of Seimatosporium. Because intraspecific variation in virulence of some grapevine trunk pathogens is reported-for example, Diaporthe ambigua (Lawrence et al. 2015), Diplodia seriata (Luque et al. 2009), and E. lata (Sosnowski et al. 2007)_individual inoculations of the trunk pathogens provided a means of evaluating our isolates in the context of the published literature. In spite of attempts to produce spores of all 10 isolates in culture, three species of trunk pathogens $C$. ampelina Wint015, Diatrypella verruciformis Napa016, and E. lata Napa003 never produced spores. As such, mycelial suspensions were used as a uniform source of inoculum for all isolates, to examine in planta interactions. For each isolate, mycelial suspensions were prepared as inoculum (6-day-old potato dextrose broth [PDB] cultures were homogenized with a hand-held disperser), following the protocol of Travadon et al. (2013).

The experimental design consisted of two repeated experiments, which were performed, starting 1 week apart, on two sets of plants propagated in two separate greenhouses. In each experiment, eight plants were inoculated per each of 10 isolates and eight plants were dual inoculated per each of five pairs of isolates. Wounded but noninoculated controls were wounded once or twice (eight plants per control treatment), to evaluate the effect of one versus two wounds on lesion length in the absence of inoculum. Therefore, there were 17 inoculation treatments, giving a total of 272 plants (eight plants $\times$ 17 treatments $\times$ two experiments). Plants were arranged in a completely randomized design in both greenhouses.

Dormant cuttings of Vitis vinifera L. 'Pinot noir' ENTAV-INRA clone 777 were propagated in the greenhouse according to Travadon et al. (2013). Briefly, starting in April 2016, cuttings were callused at

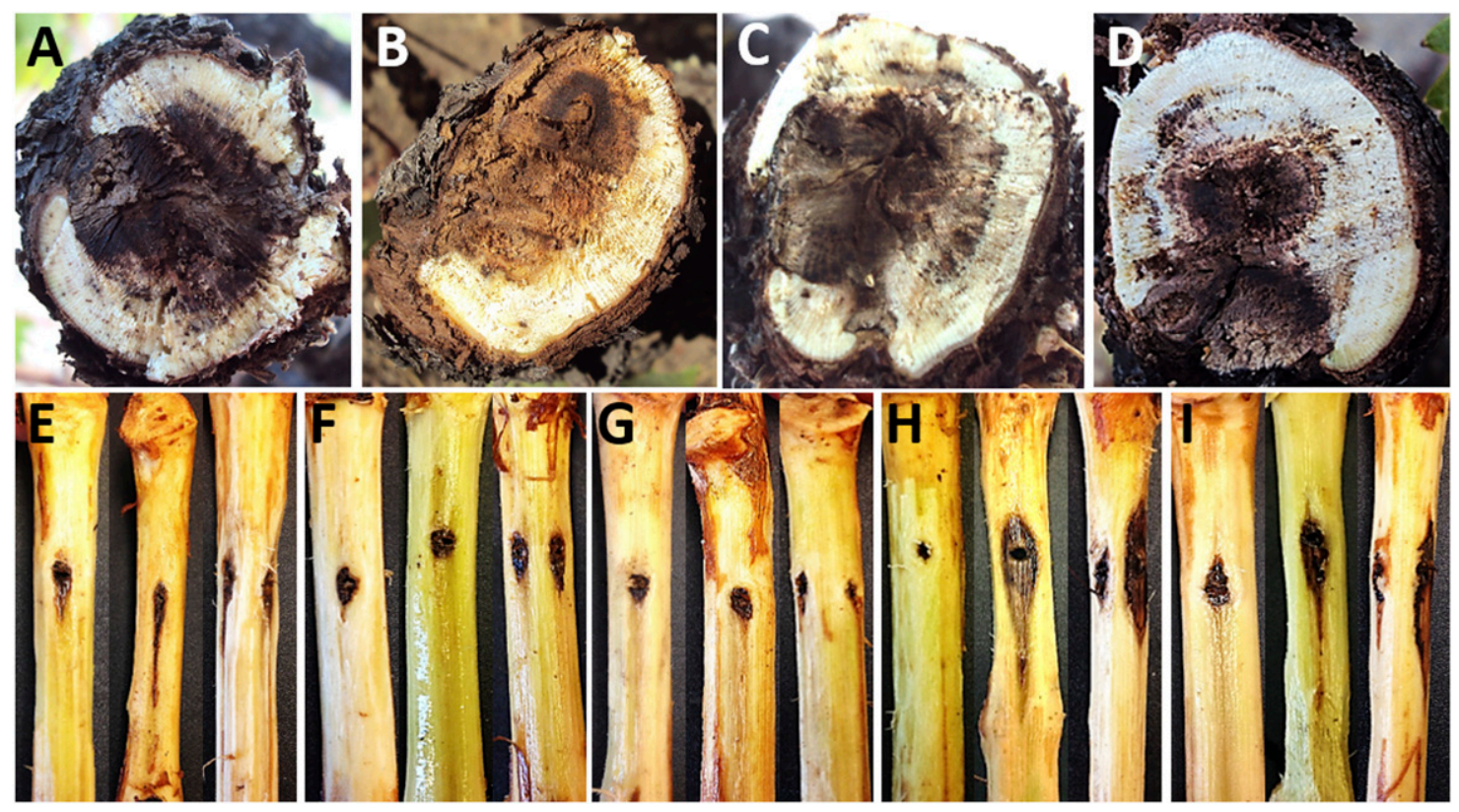

Fig. 1. A to C, Wood cankers from which Seimatosporium isolates and trunk pathogens were originally isolated were asymmetric in shape, dark brown to light brown in color, and appeared to grow out from the internal heartwood of the grapevine cordons, with black spotting in the surrounding wood closer to the bark. D, Wood cankers were sometimes darker in color, but were still present within the heartwood and surrounded by outer layers of wood with black spotting. Stem lesions that formed on plants in single and dual inoculations with five pairs of species: E, Seimatosporium vitis Napa774 and Eutypa lata Napa003; F, S. vitis Napa782 and Diatrypella verruciformis Napa016; G, S. vitifusiforme Wint753 and Cryptovalsa ampelina Wint015; H, S. vitifusiforme Napa768 and Diplodia seriata Napa810; and I, S. luteosporum Wint754 and Diaporthe ambigua Wint904. 
$30{ }^{\circ} \mathrm{C}$ and $100 \%$ humidity in a mixture of perlite and vermiculite $(1: 1$, $\mathrm{vol} / \mathrm{vol}$ ) for 21 days. Once shoot and root initials emerged from the callus tissue, a power drill was used to produce a wound $(2 \mathrm{~mm}$ in width by $3 \mathrm{~mm}$ in depth) approximately $2 \mathrm{~cm}$ below the uppermost node. For dual inoculations, two wounds were made per stem, with each wound approximately $5 \mathrm{~mm}$ apart and $2 \mathrm{~cm}$ below the uppermost node. Inoculum $(20 \mu \mathrm{l})$ was pipetted into the wound, which was then sealed with Vaseline (Unilever, Rotterdam, London) and Parafilm (Bemis Co., Neenah, WI) to prevent inoculum desiccation. An equal volume $(20 \mu \mathrm{l})$ of sterile PDB was pipetted into the wound of noninoculated controls. Cuttings were coated with melted paraffin wax (Gulf Wax; Royal Oak Enterprises, LLC, Roswell, GA), to prevent moisture loss, and potted in sterile potting mix amended with slow-release fertilizer (Osmocote Pro 24-4-9; Scotts, Marysville, $\mathrm{OH})$. Plants were grown in the greenhouse at the University of California Experiment Station in Davis from June 2016 to May 2017 (natural sunlight photoperiod, $25 \pm 1$ and $18 \pm 3^{\circ} \mathrm{C}$, day and night, respectively), with some modifications to the temperature conditions $\left(10 \pm 2\right.$ and $4 \pm 2{ }^{\circ} \mathrm{C}$, day and night, respectively) during dormancy (for 2 months starting in December 2016). Plants were watered four times per week for 15 min using a drip-irrigation system $\left(0.5\right.$ liters $\left.\mathrm{h}^{-1}\right)$.

The length of internal wood discoloration extending out from the inoculation site up and down the stem (lesion length) was measured approximately 11 months after inoculation in April 2017 during the second growing cycle. First, the newly developed green shoots, roots, and bark of each plant were removed and discarded, and the woody stems were surface sterilized in $1 \%$ sodium hypochlorite for $2 \mathrm{~min}$ and rinsed with deionized water. The length of each stem was recorded and cut longitudinally to expose wood discoloration, the length of which was measured with a digital caliper. To confirm that the isolate was responsible for wood discoloration in inoculated plants, recovery was attempted by cutting 10 pieces ( 2 by 5 by $5 \mathrm{~mm}$ ) of wood from the distal margin of the lesion, followed by surface disinfestation in $0.6 \%$ sodium hypochlorite ( $\mathrm{pH} 7.2$ ) for $30 \mathrm{~s}$, two $30-\mathrm{s}$ rinses in sterile deionized water, plating on PDA amended with tetracycline $\left(1 \mathrm{mg} \mathrm{liter}^{-1}\right)$, and incubation in the dark at approximately $22^{\circ} \mathrm{C}$ for 14 to 21 days. Plants that died during the course of the study, which sometimes occurs due to improper rooting, were excluded from analyses of lesion lengths and from recovery attempts.

Lesion lengths among inoculated plants relative to those of noninoculated plants were used as a measure of pathogenicity. Normality and homogeneity of variances were evaluated using normal probability plots and Levene's test, respectively. ANOVAs were used to determine whether there were differences in lesion length among isolates when inoculated alone or in pairs relative to noninoculated plants, and if this was consistent between two replicate experiments. There was a separate ANOVA for each pair of isolates, with all datasets including lesion lengths from the same set of noninoculated plants. ANOVAs were performed using the MIXED procedure in SAS, with inoculation treatment, experiment, and their interaction considered as fixed effects. Means were calculated using the LSMEANS procedure. For significant effects $(P<0.05)$, means were compared by Tukey's tests.

Fungal interactions in vitro. In vitro evaluation of fungal interactions between pairs of Seimatosporium isolates and trunk pathogens originating from the same canker was conducted on dual-inoculated PDA plates (three plates per pair of isolates) following a protocol adapted from Kotze et al. (2011). Because Seimatosporium isolates grow relatively slowly, they were cultured for 10 days on the pairing plates before adding mycelial plugs of the coisolated trunk pathogens to each plate. Two mycelial plugs ( 2 by $2 \mathrm{~mm}$ ) from the margin of a 7-day-old Seimatosporium colony were plated $2 \mathrm{~cm}$ apart on PDA and incubated for 10 days at $22^{\circ} \mathrm{C}$ in darkness. After 10 days, two mycelial plugs ( 2 by $2 \mathrm{~mm}$ ) from the margin of a 7-day-old colony of each coisolated trunk pathogen were plated $2 \mathrm{~cm}$ from the Seimatosporium plugs, hence allowing for one self-pairing per Seimatosporium isolate and two allo-pairings per pair of isolates on the same plate. Dual-inoculated plates were then incubated for an additional 12 days at $22^{\circ} \mathrm{C}$ in darkness. Microscopic observations of fungal interactions were observed at $\times 100$ by removing mycelial plugs ( 2 by
$2 \mathrm{~mm}$ ) from the interaction zone and placing them on a glass slide with sterile deionized water, as described by Kotze et al. (2011).

\section{Results}

Phylogenetic analyses. The best-fit model of nucleotide evolution for ML analyses were deduced based on the AIC (K2 + G for ITS, $\mathrm{K} 2+\mathrm{G}+\mathrm{I}$ for ITS + LSU, and $\mathrm{K} 2+\mathrm{G}$ for ITS + LSU + TEF1- $\alpha+$ $\mathrm{BT})$. Alignment of the two-locus dataset (ITS + LSU) resulted in a 1,364-character dataset $(1,100$ characters were constant, 127 characters were parsimony uninformative, and 137 characters were parsimony informative). MP analysis produced a single most parsimonious tree of 422 steps and a consistency index (CI) and retention index (RI) of 0.504532 and 0.802410 , respectively. ML and MP analyses revealed that 10 of our Seimatosporium isolates from grape in California clustered with strong support (96 and 99\% ML and MP bootstrap values, respectively) with the ex-type of $S$. vitis isolate MFLUCC 14-0051. Fifteen isolates clustered in a weakly supported clade (60 and 70\%) and, within this, was a strongly supported (100 and 100\%) subclade of two isolates (Fig. 2). With no apparent type or nontype affiliations for either clade, however, additional analyses were required.

Stronger support for the phylogenetic subdivision of these 15 isolates into two clades was obtained with analyses of ITS-only (Supplementary Fig. S1) and ITS + LSU + TEF1- $\alpha+$ BT datasets (Supplementary Fig. S2). We propose these two clades to be novel taxa, hereinafter identified as Seimatosporium vitifusiforme sp. nov. and Seimatosporium luteosporum sp. nov. Alignment of ITS sequences resulted in a 562-character dataset (377 characters were constant, 84 characters were parsimony uninformative, and 101 characters were parsimony informative). MP analyses produced two equally most-parsimonious trees of 312 steps and a CI and RI of 0.522449 and 0.815457, respectively. ML and MP analyses of the ITS + LSU dataset (Fig. 2) produced topology and bootstrap values similar to those in the ITS-only analysis, with increased support for the aforementioned newly discovered taxa. The major topological differences between the ITS-only and ITS + LSU analyses were the order of divergence among other phylogenetically close genera, Adisciso Kaz. Tanaka, Okane \& Hosoya, Immersidiscosia Kaz. Tanaka, Okane \& Hosoya, Sarcostroma Cooke, Synnemapestaloides T. Handa \& Y. Harada, and fungi previously identified as S. ficeae, S. rhombisporum, and $S$. pezizoides (Ellis \& Everh.) B. Sutton. The latter three taxa require taxonomic revision based on our phylogenetic analyses, because all three cluster distantly from Seimatosporium spp.

Alignment of the four-loci dataset (ITS + LSU + TEF1- $\alpha+$ BT) resulted in a 2,229-character dataset (2,023 characters were constant, 91 characters were parsimony uninformative, and 115 characters were parsimony informative). MP analysis produced 10 equally most-parsimonious trees of 206 steps and a CI and RI of 0.968254 and 0.995781 , respectively. ML and MP analyses revealed that all three Seimatosporium spp. recovered from symptomatic grapevine cankers in northern California are strongly supported $(\geq 82$ and $\geq 99 \%$, respectively) as independent phylogenetic lineages.

Morphology. Average colony growth at $25^{\circ} \mathrm{C}$ after 14 days was significantly different among the 25 Seimatosporium isolates $\left(P\left[F_{(21,44)}>39\right]<0.0001\right)$, with $S$. vitifusiforme Napa796 producing the smallest colony $(33.5 \mathrm{~mm})$ and $S$. vitis Napa784 the largest colony $(75.7 \mathrm{~mm})$. Nonetheless, there was large variation among colony growth within a species (e.g., from 33.5 to $64.8 \mathrm{~mm}$ for $S$. vitifusiforme). S. vitifusiforme produced a buff, cottony, medium-growing colony with a smooth, lighter colored margin. $S$. luteosporum produced a grayish-white, cottony, medium-fast growing colony with a smooth margin. $S$. vitis produced a light- to medium-brown, cottony, medium-fast growing colony with a smooth, light-colored margin. There were significant differences in conidial length $\left(P\left[F_{(2,87)}>\right.\right.$ $92.28]<0.0001)$ and width $\left(P\left[F_{(2,87)}>129.06\right]<0.0001\right)$ among the three species, with $S$. vitifusiforme Wint 753 producing, on average, the longest and most narrow conidia as compared with $S$. luteosporum and $S$. vitis, as described below.

Taxonomy. Morphological comparisons, coupled with phylogenetic analyses (ML and MP) of the ITS + LSU + TEF1- $\alpha+$ BT dataset, identified three distinct and strongly supported clades, two of 
which have no apparent species names. Thus, we propose the following new species names to properly circumscribe and typify these two unique taxa:

Seimatosporium vitifusiforme D. P. Lawr. \& Travadon, sp. nov. MycoBank number: MB820361; Figures 2 and 3.

Typification. USA, California: Solano County, $38.5249^{\circ} \mathrm{N}$, $121.9708^{\circ} \mathrm{W}, 41 \mathrm{~m}$ above sea level (masl) isolated from wood canker of $V$. vinifera, 2010, R. Travadon number Wint753 (holotype BPI 910344, dried culture; ex-type CBS 142600). GenBank accession numbers: KY706296, ITS; KY706271, BT; KY706346, TEF1- $\alpha$; KY706321, LSU.

Etymology: The name refers to the host (V. vinifera) and to the fusiform shape of the conidia.

Colony diameter of $S$. vitifusiforme isolate Wint753: $51.6 \mathrm{~mm}$ in 14 days at $25^{\circ} \mathrm{C}$ on PDA, medium-growing, slightly raised, wooly

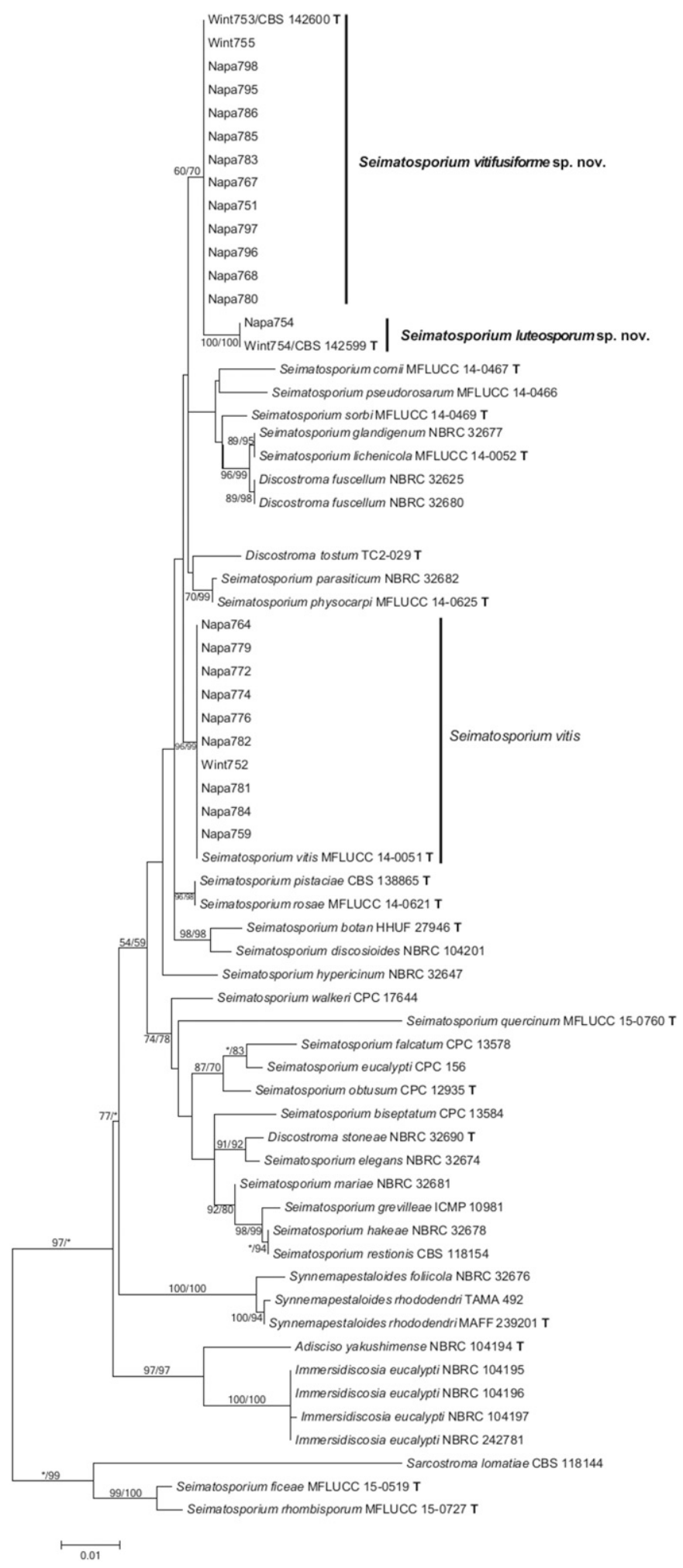

Fig. 2. Single most likely tree (In likelihood -4439.3212) resulting from the combined analysis of internal transcribed spacer and large subunit sequences from 65 Seimatosporium isolates and closely related genera. Numbers represent maximum-likelihood/maximum-parsimony bootstrap values, respectively. Values represented by an asterisk were less than $50 \%$. Scale bar represents the expected number of substitutions per site. Ex-type strains of Seimatosporium luteosporum sp. nov. and Seimatosporium vitifusiforme sp. nov. are CBS 142599 (Wint754) and CBS 142600 (Wint753), respectively. 
light-brown colony with smooth wooly off-white margin. Hyphae hyaline, smooth, straight, branched, and septate. Conidiomata pycnidioid, mostly solitary some aggregate, dark, globose, 258-(392)-525 $\mu \mathrm{m}$ in diameter $(n=30)$. Conidiophores reduced to conidiogenous cells, simple, holoblastic, $11.9-(15.5)-26.4 \times 1.5-(1.9)-2.6 \mu \mathrm{m}(n=30)$. Conidia 18.6-(24.9)-30.3 × 3.7-(4.2)-5.1 $\mu \mathrm{m}(n=50)$, abundant, single, concolorous median cells, smooth-walled, curved toward apex, three-septate, slight constriction at some septa; basal cell hyaline to pale brown, truncate base, 3.3-(4.4)-5.6 $\mu \mathrm{m}$ with single eccentric, hyaline, unbranched, flexuous appendage 3.9-(9.5)-16.6 $\mu \mathrm{m}$; median cells light to medium brown, cylindrical, second cell from base 4.9-(6.1)-7.6 $\mu \mathrm{m}$, third cell from base 4.3-(7.1)-8.9, together 9.2-(13.2)-16.5 $\mu \mathrm{m}$, transverse septa thick and dark brown; apical cell hyaline to pale brown, $4-(6.3)-8.1 \mu \mathrm{m}$ with conical apex, with single, central, hyaline, unbranched, flexuous appendage 7-(10)-12.6 $\mu \mathrm{m}$. No teleomorph observed. Known distribution: Napa and Solano Counties, California, USA.

Seimatosporium luteosporum D. P. Lawr. \& Travadon, sp. nov. MycoBank number: MB820362; Figures 2 and 4.

Typification. USA, California: Solano County, $38.5249^{\circ} \mathrm{N}$, $121.9708^{\circ} \mathrm{W}, 41$ masl isolated from wood canker of $V$. vinifera, 2010, R. Travadon number Wint754 (holotype BPI 910345, dried culture; ex-type CBS 142599). GenBank accession numbers: KY706284, ITS; KY706259, BT; KY706334, TEF1- $\alpha$; KY706309, LSU.

Etymology: The name refers to the characteristic concolorous yellow-orange pigmentation of the two median cells within a conidium.

Colony diameter of $S$. luteosporum isolate Wint754: $64.5 \mathrm{~mm}$ in 14 days at $25^{\circ} \mathrm{C}$ on PDA, medium-fast growing, grayish white, slightly raised, wooly colony with smooth margin. Hyphae hyaline, smooth, straight, branched, and septate. Conidiomata pycnidioid, mostly solitary some aggregate, dark, 345-(468)-568 $\mu \mathrm{m}$ in diameter $(n=30)$. Conidiophores reduced to conidiogenous cells 12.6 (17.4)-25.1 × 1.8-(2.3)-2.6 $\mu \mathrm{m}(n=30)$. Conidia 16.7-(19.9)$25.4 \times 4.7-(5.3)-5.6 \mu \mathrm{m}(n=50)$, abundant, single, pale luteous concolorous median cells, smooth-walled, slightly curved at both ends, three-septate, slight constriction at some septa; basal cell hyaline to buff, truncate base, 2.1-(3.2)-4.6 $\mu \mathrm{m}$ with single eccentric, hyaline, unbranched, flexuous appendage 9.8-(16.7)-23.6 $\mu \mathrm{m}$; median cells pale luteous, cylindrical, second cell from base 3.8-(5.6)-8.1 $\mu \mathrm{m}$, third cell from base 4.4-(6.1)-7.5, together 8.2-(11.8)-15.6 $\mu \mathrm{m}$, transverse septa thick and cinnamon colored; apical cell hyaline to buff, 2.5-(3.7)-4.9 $\mu \mathrm{m}$ with conical apex, with single, central, hyaline, unbranched, elongated flexuous appendage 10.1-(17.9)-24.2 $\mu \mathrm{m}$. No teleomorph observed. Known distribution: Napa and Solano Counties, California, USA.

\section{Seimatosporium vitis Y. P. Xiao, Camporesi \& K. D. Hyde}

Index Fungorum number: IF551200; MycoBank number: MB551200

Colony diameter of $S$. vitis isolate Napa782: $59.8 \mathrm{~mm}$ in 14 days at $25^{\circ} \mathrm{C}$ on PDA, medium growing, light brown, slightly raised, wooly colony with smooth margin. Hyphae hyaline, smooth, straight, branched, and septate. Conidiomata pycnidioid, mostly solitary some aggregate, dark, 112-(221)-368 $\mu \mathrm{m}$ in diameter $(n=30)$. Conidiophores reduced to conidiogenous cells 8.1-(12.1)-21.5 × 1.4-(2.1)-3 $\mu \mathrm{m}(n=$ 30). Conidia abundant, single, concolorous median cells, smoothwalled, mostly straight some slightly curved, three-septate, slight constriction at most septa 13-(16.1)-19.7 × 4.9-(5.5)-5.9 $\mu \mathrm{m}(n=$ 50); basal cell hyaline to pale brown, truncate base, $2-(3)-4.5 \mu \mathrm{m}$ with single eccentric, hyaline, unbranched, short flexuous appendage 4.5-(6.7)-10.9 $\mu \mathrm{m}$; median cells light to medium brown, doliiform,
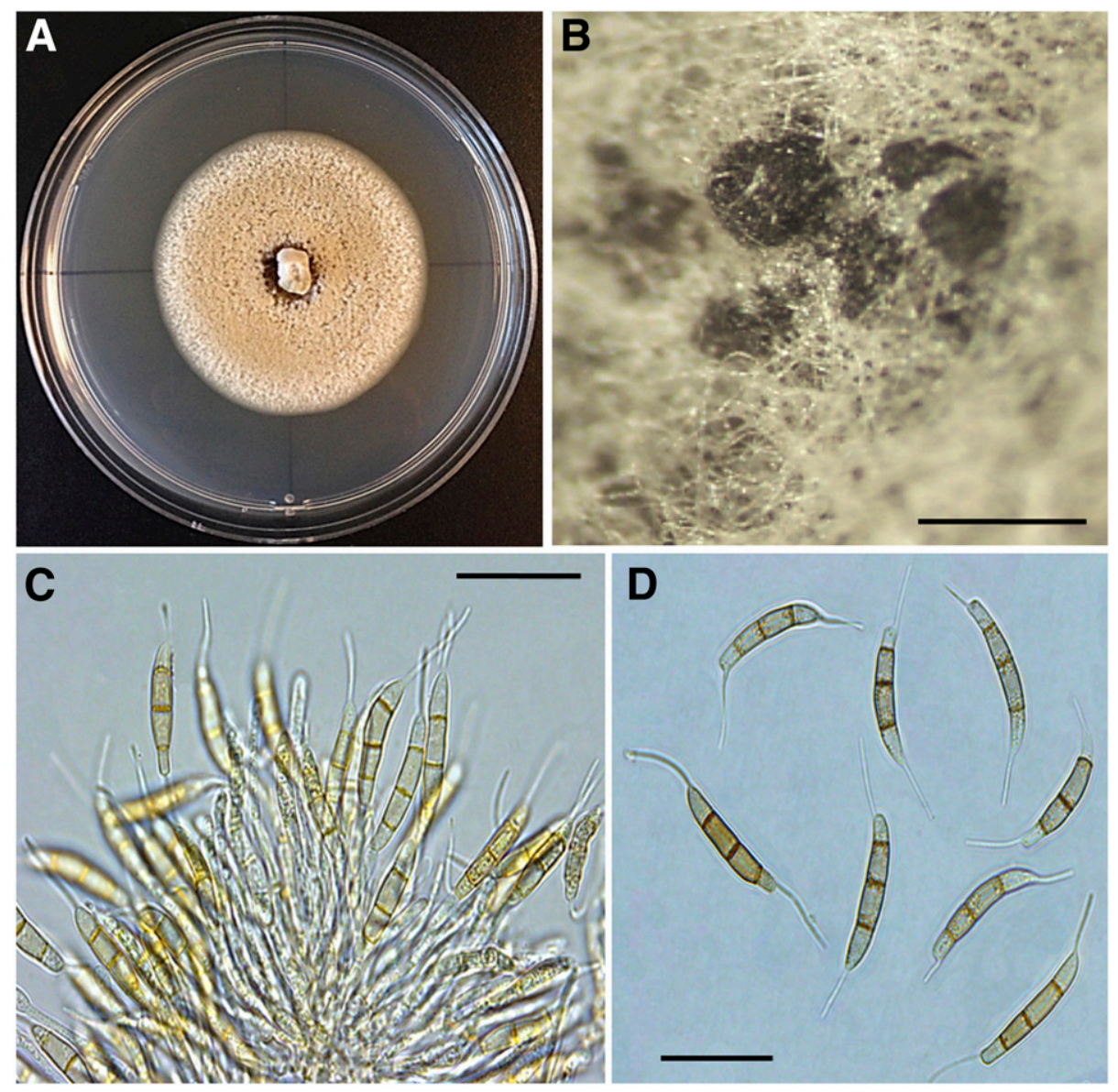

Fig. 3. A, Morphology of Seimatosporium vitifusiforme Wint753, ex-type CBS 142600 . Colony cultured on potato dextrose agar at $25^{\circ} \mathrm{C}$ in the dark for 14 days. B, Pycnidia produced on autoclaved grapevine wood. C, Conidiogenous cells with appendage-bearing conidia. D, Multiseptate conidia with single apical centrally located appendage and single basal eccentrically located appendage. Scale bars: $500 \mu \mathrm{m}(\mathrm{B})$ and $25 \mu \mathrm{m}(\mathrm{C}$ and D). 
second cell from base 2.9-(3.8)-5.5 $\mu \mathrm{m}$, third cell from base 2.6-(3.8)-5.6, together 8.2-(11.8)-15.6 $\mu \mathrm{m}$, transverse septa very thick and medium to dark brown; apical cell hyaline to pale brown, 2.8-(3.6)-4.2 $\mu \mathrm{m}$ with conical apex, with single, central, hyaline, unbranched, short flexuous appendage 2.8-(7.3)-12 $\mu \mathrm{m}$. No teleomorph observed. Known distribution: Napa and Solano Counties, California USA, Hungary, Iran, and Italy. The teleomorph of S. vitis was recently described by Mehrabi et al. (2017).

Based on phylogenetic results, we propose the following taxonomic revision to produce a more stable taxonomy, because Sarcostroma restionis clearly belongs in Seimatosporium:

Seimatosporium restionis (S. J. Lee \& Crous) D. P. Lawr. \& Travadon comb. nov.

MycoBank number: MB821608; Figure 2.

Basionym: Sarcostroma restionis S. J. Lee \& Crous (Lee et al. 2006).

Fungal interactions in planta. The wood cankers from which the Seimatosporium isolates originated were irregular in shape, with discolored and necrotic wood mostly present within the heartwood, colored various shades of brown, and frequently surrounded by black spotting or occlusions of the wood (Fig. 1A to D). After an 11-month incubation in the woody stems of potted Pinot noir plants, all fungal isolates inoculated singly and together caused lesions (Fig. 1E to I), which were similar in color and texture to the wood cankers from which they were isolated. No expression of foliar symptoms was observed. Recovery of isolates was confounded by frequent contamination of fast-growing, naturally occurring endophytes, primarily Trichoderma Pers. and Alternaria Nees. Only the fast-growing species Diaporthe ambigua Wint904 and Diplodia seriata Napa810 were reisolated from 53 and $63 \%$ of inoculated plants, respectively. Seimatosporium spp., which grew particularly slowly, were not recovered from any inoculated plants and, thus, their pathogenic status remains unclear.

For each pair of isolates, ANOVA showed that mean lesion lengths of the inoculation treatments (control, single inoculations with either isolate, and dual inoculations with both isolates) were not significantly different between the two replicate experiments $(P$ values of 0.1 to 1.0$)$. The only significant effect was inoculation treatment ( $P$ values of 0.001 to $<0.0001)$. Effects of inoculation treatment were consistent between the two replicate experiments, because there was no significant effect of the interaction between experiment and inoculation treatment ( $P$ values of 0.1 to 0.4 ). Lesions associated with single inoculations of $S$. vitifusiforme Napa768 were not significantly different from those of the control, based on the results of
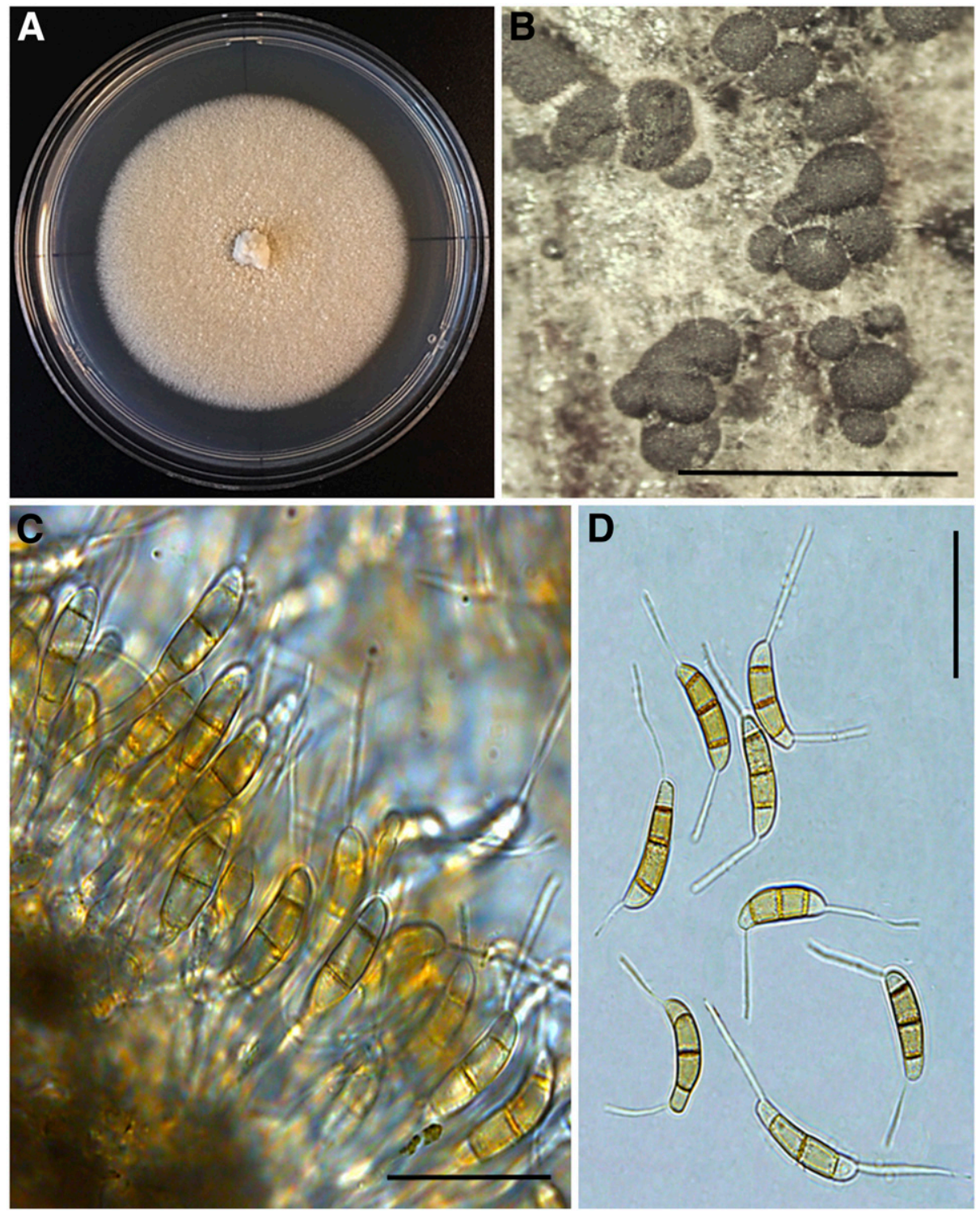

Fig. 4. A, Morphology of Seimatosporium luteosporum Wint754, ex-type CBS 142599 . Colony cultured on potato dextrose agar at $25^{\circ} \mathrm{C}$ in the dark for 14 days. B, Pycnidia produced on autoclaved grapevine wood. C, Conidiogenous cells with appendage-bearing conidia. D, Multiseptate conidia with single apical centrally located appendage and single basal eccentrically located appendage. Scale bars: $1 \mathrm{~mm}(\mathrm{~B})$, and $25 \mu \mathrm{m}(\mathrm{C}$ and $\mathrm{D})$. 
means comparisons (Fig. 5A). However, S. vitifusiforme Napa768 was associated with significantly larger lesions than those of the control when dual inoculated with $D$. seriata Napa810, the latter of which in both single and dual inoculations was associated with the largest lesion lengths in our study. Larger lesions for both S. vitifusiforme Napa768 (statistically significant) and D. seriata Napa810 (not statistically significant but, nonetheless, larger) suggest that there is a synergistic effect of dual inoculation on lesion length. We found similar increases in lesion lengths in dual inoculations of $S$. luteosporum Wint754 and Diaporthe ambigua Wint904, with S. luteosporum Wint754 associated with lesions larger than those of the controls only in dual inoculation with D. ambigua Wint904 (Fig. 5B). Unlike S. vitifusiforme Napa768, plants inoculated with $S$. vitifusiforme Wint753 in single inoculations had larger lesions than the controls (Fig. 5C). Furthermore, dual inoculations of S. vitifusiforme Wint753 and C. ampelina Wint 015 brought about larger lesions for C. ampelina Wint015, which was not pathogenic in single inoculations.

Plants inoculated with $S$. vitis Napa782 in single inoculations had larger lesions than those of the control but dual inoculations with Diatrypella verruciformis Napa016 were not associated with lesion length increases for either isolate (Fig. 5D). Both S. vitis Napa774 and E. lata Napa003 had significantly longer lesion lengths than those of the controls in single and dual inoculations; however, dual inoculations were not associated with significantly larger lesions for either isolate (Fig. 5E).

Fungal interactions in vitro. In vitro, we observed three types of fungal interactions between different species: no to sparse growth in a band of uncolonized or sparsely colonized media (clearing zone), formation of a band of dark pigmented hyphae (barrage zone), and dense growth of both species in direct contact with each other to sometimes form a "wall" of hyphae. In contrast, there was no evidence of growth inhibition in self-pairings between agar plugs of the same isolate; hyphae originating from both plugs merged into a single colony.

The interactions between S. vitis Napa774 and E. lata Napa003 and between $S$. vitis Napa782 and D. verruciformis Napa016 appeared to be antagonistic in vitro. A clearing zone formed between $S$. vitis Napa774 and E. lata Napa003, and the aerial hyphae of E. lata Napa003 changed color from white to off-white on the surface of the agar and to orange within the agar (Fig. 6A). Between the clearing zone and the agar plug, each isolate formed a dark, pigmented barrage zone (visible on the underside of the plate), which was particularly thick for E. lata Napa003 (Fig. 6A). Microscopic examination showed the hyphae of $E$. lata were swollen near the clearing zone (Fig. 6B). The interaction of $S$. vitis Napa782 and D. verruciformis

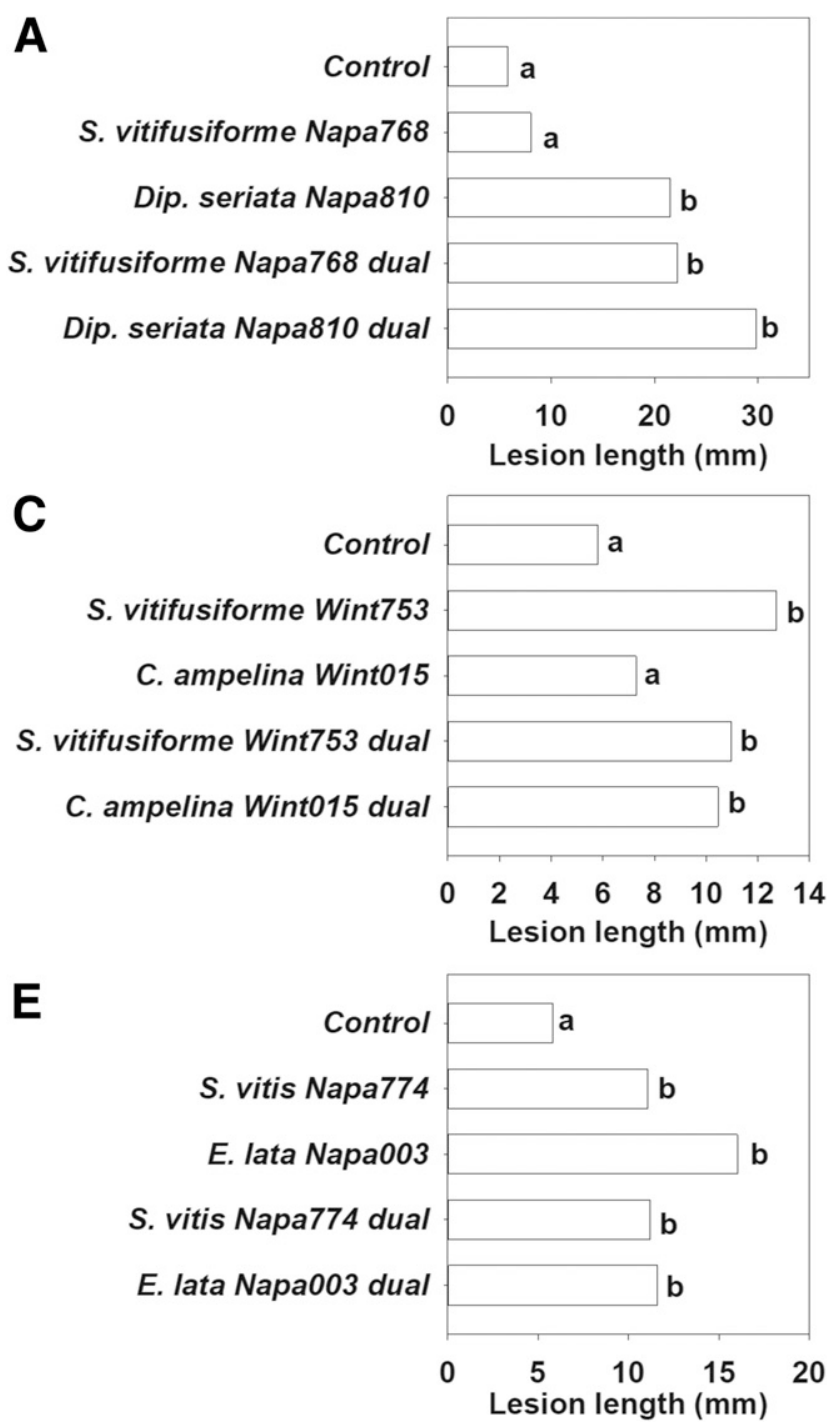

B
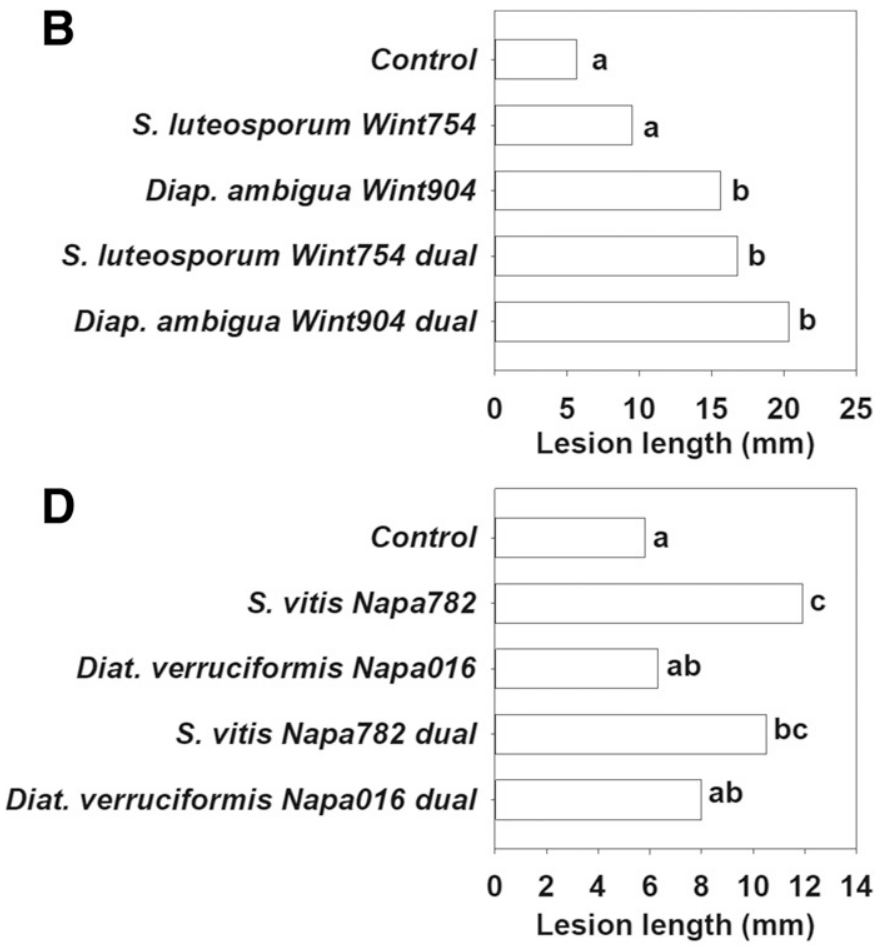

Fig. 5. In planta interactions after 11 months in the stems of Vitis vinifera 'Pinot noir' potted plants between pairs of species originating from the same wood cankers. A, Seimatosporium vitifusiforme Napa768 and Diplodia seriata Napa810; B, S. luteosporum Wint754 and Diaporthe ambigua Wint904; C, S. vitifusiforme Wint753 and Cryptovalsa ampelina Wint015; D, S. vitis Napa782 and Diatrypella verruciformis Napa016; and E, S. vitis Napa774 and Eutypa lata Napa003. Mean lesion lengths for single and dual inoculations each represent 9 to 14 observations, summed across replicate experiments. Mean lesion lengths of control plants (wounded, but noninoculated) represent 29 observations, summed across single and dual control plants, in both replicate experiments. Means with the same letter, within each graph, are not significantly different (Tukey's test, $P<0.05, \alpha=0.05$ ). 
Napa016 was similar, with a clearing zone between the two isolates and pigmented barrage zones closer to the agar plugs, especially within the colony of D. verruciformis Napa016 (Fig. 6C). Microscopic examination revealed D. verruciformis Napa016 produced swollen, bulb-shaped hyphae near the clearing zone (Fig. 6D).

The interaction between $S$. vitifusiforme Wint753 and C. ampelina Wint015 appeared to be antagonistic in vitro but with less dramatic changes in colony morphology at the interaction zone than described above for pairings with $S$. vitis isolates, and no visible changes in hyphal morphology. The interaction between $S$. vitifusiforme Wint753 and C. ampelina Wint 015 resulted in the formation of a narrow barrage zone, which appeared as a wall of hyphae on the agar surface and a dark band as viewed on the underside of the plate (Fig. 6E). Both $S$. vitifusiforme Wint753 and C. ampelina Wint015 had a high density of hyphae right up to the barrage zone; there was no clearing zone and the hyphae of neither isolate were swollen or misshapen (Fig. 6F).

The interactions between S. vitifusiforme Napa768 and Diplodia seriata Napa810 and between S. luteosporum Wint754 and Diaporthe ambigua Wint904 showed the least degree of growth inhibition to either species in each pairings. There was no clearing zone between S. vitifusiforme Napa768 and Diplodia seriata Napa810 (Fig. 6G). Microscopic examination revealed hyphae of both species were intermixed (Fig. 6H). The interaction of S. luteosporum Wint754 and Diaporthe ambigua Wint904 resulted in a very narrow clearing zone between the two species (Fig. 6I). Microscopic examination revealed hyphae of each species were restricted with clear separation (Fig. 6J).

\section{Discussion}

This study is the first to explore the diversity and pathogenicity of Seimatosporium spp. isolated from grapevines with symptoms of grapevine trunk diseases in northern California. Three species of Seimatosporium were identified by incorporating reference type and nontype sequences in phylogenetic analyses. Two of the species, S. luteosporum and S. vitifusiforme, are newly described and typified, whereas the third, S. vitis, constitutes a new report from North America. The Seimatosporium spp. associated with grapevine and other perennial hosts (e.g., Eucalyptus) (Barber et al. 2011) have likely been overlooked, due in part to the lack of type or ex-type sequence data in molecular repositories. Indeed, our species-level identification was restricted mainly to analyses of ITS and LSU sequences, because there is a dearth of potentially more-informative protein-coding loci in GenBank for Seimatosporium spp. and allied genera. Therefore, we amplified BT and TEF1- $\alpha$ in order to provide such data for future analyses by other mycologists and plant pathologists. Future systematic studies of Seimatosporium and related genera in the family Sporocadaceae would benefit from the phylogenetic analysis of protein-coding loci such as BT and TEF1- $\alpha$ to better refine organismal relationships.

Seimatosporium and allied pestalotioid genera have several morphological features in common, which confound species identification. Since its inception in 1833, the generic concept of Seimatosporium has undergone considerable change. Indeed, from 1964 to 1980, the generic limits were broadened to accept as many as 15 generic synonyms (Nag Raj 1993). Sutton (1980) acknowledged the morphological heterogeneity of members of the genus and suggested reinstatement of certain generic names, to delimit a proper generic concept for Seimatosporium. Nag Raj (1993) further subdivided Seimatosporium spp. into what he called "five natural groups", based on conidial characteristics of extant generic names, including (i) Seimatosporium sensu stricto, (ii) Sporocadus Corda, (iii) Sarcostroma, (iv) Diploceras (Sacc.) Died., and (v) Vermisporium H. J. Swart \& M. A. Will. Seimatosporium sensu Nag Raj produces conidia with concolorous pigmented median cells, with or without a single apical or basal appendage. However, this narrow morphological concept does not reflect the true natural morphological diversity of Seimatosporium spp. and, furthermore, has been refuted by molecular phylogenetic analyses (Barber et al. 2011; Tanaka et al. 2011). Indeed, our phylogenetic analyses showed that Sarcostroma and also Discostroma Clem. (Seimatosporium teleomorph) intermixed within the Seimatosporium clade, suggesting that additional taxonomic revisions are necessary. Reassessment of the Seimatosporium phylogeny would benefit from additional collections and examination of the holomorphs to help guide morphomolecular taxonomy in this group of fungi.

Three species of Seimatosporium (S. botan, S. hysterioides, and $S$. vitis) have been reported from diseased or dead grapevine wood in Australia, Chile, Hungary, Iran, Italy, and the United States (Díaz et al. 2012; Mehrabi et al. 2017; Senanayake et al. 2015; Sergeeva et al. 2005; Váczy 2017). However, there is little information on their pathogenicity. S. botan was isolated from symptomatic vines in Chile and was shown to be pathogenic on both detached green shoots (mean lesion length of $2 \mathrm{~cm}, 14$-day incubation) and woody canes and trunks of potted plants (mean lesion lengths of 5 and $4 \mathrm{~cm}$ for 7-month incubation in canes and 15-month incubation in trunks, respectively) (Díaz et al. 2012). Váczy (2017) showed that S. vitis, isolated from symptomatic vines in Hungary, was pathogenic to the green shoots of potted plants (lesion lengths of 2 to $4 \mathrm{~cm}$ ). In our study, S. vitis

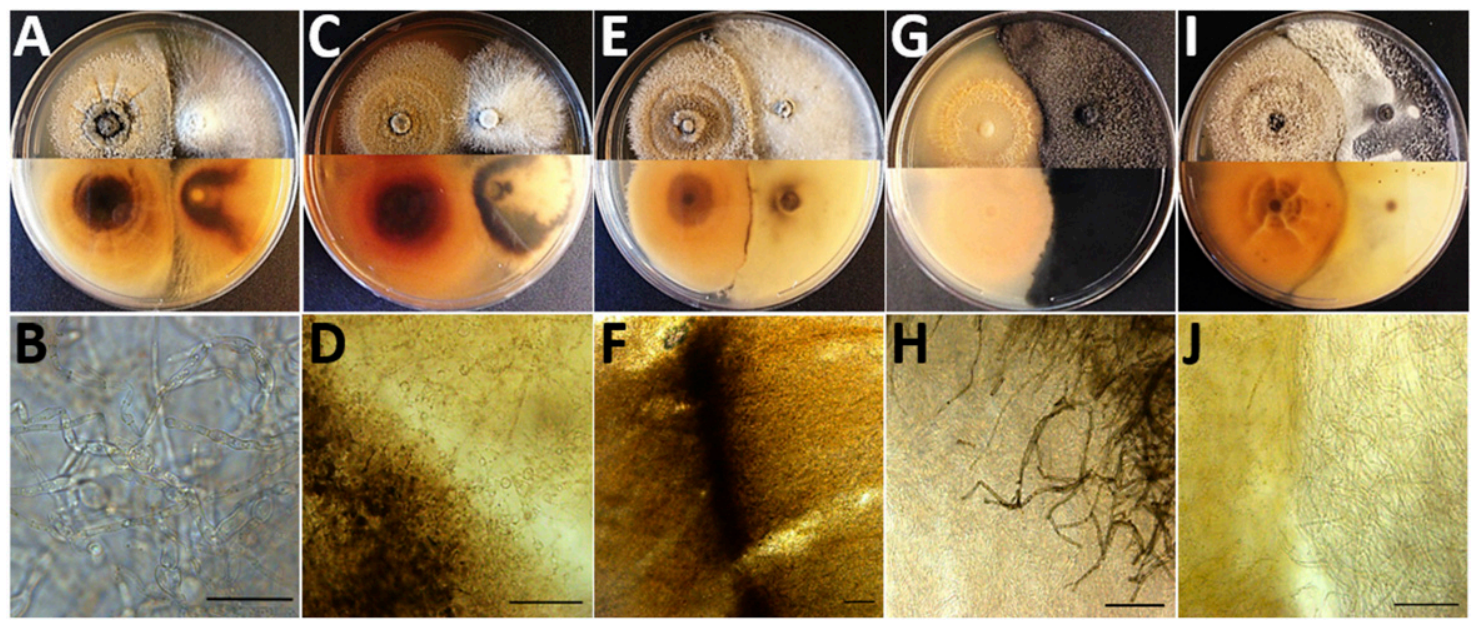

Fig. 6. In vitro interactions on potato dextrose agar (PDA) after 22 days between pairs of species originating from the same wood cankers. A, C, E, G, and I, Surface of the PDA (top) and the underside of the plate (bottom). A, Seimatosporium vitis Napa774 (left) and Eutypa lata Napa003 (right); B, swollen hyphae of E. lata Napa003 at the interaction zone; C, S. vitis Napa782 (left) and Diatrypella verruciformis Napa016 (right); D, pigmented hyphae of S. vitis Napa782 (left) and swollen, bulb-shaped hyphae of D. verruciformis Napa016 (right); E, S. vitifusiforme Wint753 (left) and Cryptovalsa ampelina Wint015 (right); F, dense hyphae of both S. vitifusiforme Wint753 (left) and C. ampelina Wint015 (right) at the interaction zone; G, S. vitifusiforme Napa768 (left) and Diplodia seriata Napa810 (right); H, dense hyphae of both S. vitifusiforme Napa768 (left) and D. seriata Napa810 (right) at the interaction zone; I, S. luteosporum Wint754 (left) and Diaporthe ambigua Wint904 (right); and J, no mixing of S. luteosporum Wint754 (left) and D. ambigua Wint904 (right) at the interaction zone. Scale bars: $25 \mu \mathrm{m}(\mathrm{B}), 100 \mu \mathrm{m}(\mathrm{D}), 100 \mu \mathrm{m}(\mathrm{F}), 100 \mu \mathrm{m}(\mathrm{H})$, and $100 \mu \mathrm{m}(\mathrm{J})$. 
produced lesions of similar size on woody stems of potted plants (range of 1- to 3-cm lesion lengths, 11-month incubation) and these were significantly greater than those of the noninoculated controls. Because $S$. botan and S. vitis are pathogenic to both green shoots and woody tissues, it is possible that, like other trunk pathogens (e.g., D. ampelina) (Wilcox et al. 2015), these species can infect different grapevines tissues through various types of wounds such as the small cracks that form on the surface of rapidly expanding green shoots or thin sections of the cuticle near the peduncle of green berries, in addition to pruning wounds. The presence of wood lesions in the stems of inoculated plants suggests that, during substrate colonization, Seimatosporium spp. may damage the wood directly by secreting cell-wall-degrading enzymes (Massonnet et al. 2017; Morales-Cruz et al. 2015) or fungal toxins (Andolfi et al. 2011), as is the case for the grapevine trunk pathogens; further studies are required to test these hypotheses.

It is difficult to compare and contrast in vitro versus in planta results of fungal interactions. Lesion margins in planta likely do not delimit fungal growth, because some trunk pathogens (e.g., E. lata) (Sosnowski et al. 2007) are frequently isolated ahead of the lesion margins in the stems of inoculated plants. However, lesion length constitutes a quantitative and repeatable measure (relative to that of the noninoculated controls) of intrahost growth and virulence, an important life history trait for fungal plant pathogens. There were varying interactions between all pairs of species in vitro, the least of which was seen as no to little growth inhibition between $S$. vitifusiforme and Diplodia seriata, and S. luteosporum and Diaporthe ambigua. In planta, dual inoculations with either S. vitifusiforme and Diplodia seriata or S. luteosporum and Diaporthe ambigua resulted in larger lesion sizes for the Seimatosporium isolates compared with single inoculations (and noninoculated controls), suggesting a synergistic effect of dual inoculation with a trunk pathogen on the virulence of these Seimatosporium isolates. It is possible that the relatively mild antagonistic interactions between the two pair of species in vitro are associated with our findings of synergistic effects in planta. Synergistic interactions among fungal plant pathogens are not well characterized but interspecies signaling and metabolic exchange and complementarity are potential mechanisms (Lamichhane and Venturi 2015). Synergistic interactions can also result from the indirect effects of one fungus, including interference with the host immune response or chemical or physical modifications to the substrate, thereby stimulating colonization by another microorganism (Le May et al. 2009; Nomura et al. 2005).

The outcomes of the dual inoculations conducted in this study should not solely be interpreted with regards to the interactions between the pairs of species, because the woody tissues of grapevines typically harbor numerous microbes (Bruez et al. 2016; Travadon et al. 2016). Indeed, we isolated many fast-growing fungi (namely, species of Trichoderma) from inoculated plants, which may have prevented recovery of Seimatosporium isolates and, thus, completion of Koch's postulates. The "microbial background" in the woody tissues of inoculated plants may have influenced the intrahost growth of inoculated isolates and wood lesion development, in particular because mycoparasitic Trichoderma isolates are routinely used as biocontrol agents in cropping systems, including grapevines (Kotze et al. 2011).

The most antagonistic interactions in vitro were between $S$. vitis and E. lata, and $S$. vitis and Diatrypella verruciformis. Both clearing zones and adjacent barrage zones formed between the two pair of species in vitro. These macroscopic changes in colony morphology were also associated with microscopic morphological changes in the hyphae; namely, hyphal swelling for the two diatrypaceous fungi which, in wood-colonizing basidiomycetes, have been associated with production of antimicrobial secondary metabolites (Boddy and Hiscox 2016). If such interaction-specific compounds were associated with our observations, they would have been produced by the fungi in both in vitro and in planta assays. In this study, there were no significant changes in lesion lengths for $S$. vitis and E. lata or $S$. vitis and D. verruciformis (all of which were greater than those of the noninoculated controls) in single versus dual inoculations. Trunk pathogens produce a diverse array of toxins (Andolfi et al. 2011); antibiosis through the release of toxins, such as eutypine produced by E. lata (Tey-Rulh et al. 1991), could limit coinfection and growth, although this hypothesis has not been tested. Therefore, it is possible that the strong antagonistic interactions between the two pair of species in vitro are associated with our findings of no increased virulence in planta.

Grapevine trunk diseases are increasingly recognized as a disease complex resulting from the complex interactions between taxonomically unrelated fungi colonizing grapevine wood (Travadon et al. 2016; Whitelaw-Weckert et al. 2013). Now, modern study tools are available to conduct unifying experiments to examine common versus distinctive virulence factors expressed by pathogens that make up the mixed infections commonly found in the field (Morales-Cruz et al. 2018). It is critical to elucidate fungal interactions in planta for the understanding of microbial pathogenesis, symptom development, and, ultimately, development of disease-management strategies (Lamichhane and Venturi 2015). In particular, some microorganisms colonizing grapevine wood may serve as biological controls (Haidar et al. 2016). Given the perennial nature of the host, the fact that pruning wounds (i.e., infection courts) are created each dormant season throughout the life of a vine, and that the wood infections via these wounds are chronic, research on mixed infections and fungal interactions will help us better understand how to maintain levels of grape yields that can bring profitability for the longest period possible.

\section{Literature Cited}

Andolfi, A., Mugnai, L., Luque, J., Surico, G., Cimmino, A., and Evidente, A. 2011. Phytotoxins produced by fungi associated with grapevine trunk diseases. Toxins (Basel) 3:1569-1605.

Arzanlou, M., Narmani, A., Moshari, S., Khodaei, S., and Babai-Ahari, A. 2013. Truncatella angustata associated with grapevine trunk disease in northern Iran. Arch Phytopathol. Plant Prot. 46:1168-1181.

Bala, K., Robideau, G. P., Désaulniers, N., De Cock, A. W. M., and Lévesque, C. A. 2010. Taxonomy, DNA barcoding and phylogeny of three new species of Pythium from Canada. Persoonia 25:22-31.

Barber, P. A., Crous, P. W., Groenewald, J. Z., Pascoe, I. G., and Keane, P. 2011. Reassessing Vermisporium (Amphisphaeriaceae), a genus of foliar pathogens of eucalypts. Persoonia 27:90-118.

Baumgartner, K., Fujiyoshi, P. T., Travadon, R., Castlebury, L. A., Wilcox, W. F., and Rolshausen, P. E. 2013. Characterization of species of Diaporthe from wood cankers of grape in eastern North American vineyards. Plant Dis. 97: 912-920.

Begon, M., Townsend, C. R., and Harper, J. L. 2006. Ecology: From Individuals to Ecosystems, 4th ed. Blackwell Publishing, Hoboken, NJ.

Boddy L., and Hiscox J. 2016. Fungal ecology: Principles and mechanisms of colonization and competition by saprotrophic fungi. Pages 293-308 in: The Fungal Kingdom. J. Heitman, B. J. Howlett, P. W. Crous, E. H. Stukenbrock, T. Y. James, and N. A. R. Gow, eds. American Society for Microbiology, Washington, DC

Bruez, E., Baumgartner, K., Bastien, S., Travadon, R., Guérin-Dubrana, L., and Rey, P. 2016. Various fungal communities colonise the functional wood tissues of old grapevines externally free from grapevine trunk disease symptoms. Aust. J. Grape Wine Res. 22:288-295.

Carbone, I., and Kohn, L. M. 1999. A method for designing primer sets for speciation studies in filamentous ascomycetes. Mycologia 91:553-556.

Díaz, G. A., Elfar, K., and Latorre, B. A. 2012. First report of Seimatosporium botan associated with trunk disease of grapevine (Vitis vinifera) in Chile. Plant Dis. 96:1696.

Glass, N. L., and Donaldson, G. C. 1995. Development of primer sets designed for use with the PCR to amplify conserved genes from filamentous ascomycetes. Appl. Environ. Microbiol. 61:1323-1330.

Goonasekara, I. D., Maharachchikumbura, S. S. N., Wijayawardene, N. N. Phookamsak, R., Schumacher, R. K., Bahkali, A. H., Gareth-Jones, E. B., and Hyde, K. D. 2016. Seimatosporium quercina sp. nov. (Discosiaceae) on Quercus robur from Germany. Phytotaxa 255:240-248.

Haidar, R., Deschamps, A., Roudet, J., Calvo-Garrido, C., Bruez, E., Rey, P., and Fermaud, M. 2016. Multi-organ screening of efficient bacterial control agents against two major pathogens of grapevine. Biol. Control 92:55-65.

Jaklitsch, W. M., Gardiennet, A., and Voglmayr, H. 2016. Resolution of morphologybased taxonomic delusions: Acrocordiella, Basiseptospora, Blogiascospora Clypeosphaeria, Hymenopleella, Lepteutypa, Pseudapiospora, Requienella, Seiridium and Strickeria. Persoonia 37:82-105.

Jayawardena, R. S., Zhang, W., Liu, M., Maharachchikumbura, S. S. N., Zhou, Y., Huang, J. B., Nilthong, S., Wang, Z. Y., Li, X. H., Yan, J. Y., and Hyde, K. D. 2015. Identification and characterization of Pestalotiopsis-like fungi related to grapevine diseases in China. Fungal Biol. 119:348-361.

Kaplan, J., Travadon, R., Cooper, M., Hillis, V., Lubell, M., and Baumgartner, K. 2016. Identifying economic hurdles to early adoption of preventative practices: The case of trunk diseases in California winegrape vineyards. Wine Econ. Policy 5:127-141. 
Kotze, C., Van Niekerk, J., Halleen, F., Mostert, L., and Fourie, P. 2011. Evaluation of biocontrol agents for grapevine pruning wound protection against trunk pathogen infection. Phytopathol. Mediterr. 50:247-263.

Lamichhane, J. R., and Venturi, V. 2015. Synergisms between microbial pathogens in plant disease complexes: A growing trend. Front. Plant Sci. 6:385.

Lawrence, D. P., Travadon, R., and Baumgartner, K. 2015. Diversity of Diaporthe species associated with wood cankers of fruit and nut crops in northern California. Mycologia 107:926-940.

Lawrence, D. P., Travadon, R., Nita, M., and Baumgartner, K. 2017. TrunkDiseaseID. org: A molecular database for fast and accurate identification of fungi commonly isolated from grapevine wood. Crop Prot. 102:110-117.

Lee, S., Crous, P. W., and Wingfield, M. J. 2006. Pestalotioid fungi from Restionaceae in the Cape Floral Kingdom. Stud. Mycol. 55:175-187.

Le May, C., Potage, G., Andrivon, D., Tivoli, B., and Outreman, Y. 2009. Plant disease complex: Antagonism and synergism between pathogens of the Ascochyta blight complex on pea. J. Phytopathol. 157:715-721.

Lorrain, B., Ky, I., Pasquier, G., Jourdes, M., Guerin-Dubrana, L., Gény, L., Rey, P., Donèche, B., and Teissedre, P.-L. 2012. Effect of Esca disease on the phenolic and sensory attributes of Cabernet Sauvignon grapes, musts and wines. Aust. J. Grape Wine Res. 18:64-72.

Luque, J., Martos, S., Aroca, A., Raposo, R., and Garcia-Figueres, F. 2009. Symptoms and fungi associated with declining mature grapevine plants in northeast Spain. J. Plant Pathol. 91:381-390.

Maddison, W. P., and Maddison, D. R. 2016. Mesquite: A modular system for evolutionary analysis. Version 3.10. Online publication. http://mesquiteproject.org

Maharachchikumbura, S. S. N., Hyde, K. D., Groenewald, J. Z., Xu, J., and Crous, P. W. 2014. Pestalotiopsis revisited. Stud. Mycol. 79:121-186.

Maharachchikumbura, S. S. N., Larignon, P., Al-Sadi, A. M., and Li, Z.-Y. 2017. Characterization of Neopestalotiopsis, Pestalotiopsis and Truncatella species associated with grapevine trunk diseases in France. Phytopathol. Mediterr. 55:380-390.

Massonnet, M., Figueroa-Balderas, R., Galarneau, E. R. A., Miki, S., Lawrence, D. P., Sun, Q., Wallis, C. M., Baumgartner, K., and Cantu, D. 2017. Neofusicoccum parvum colonization of the grapevine woody stem triggers asynchronous host responses at the site of infection and in the leaves. Front. Plant Sci. 8:1117.

Massonnet, M., Morales-Cruz, A., Figueroa-Balderas, R., Lawrence, D. P., Baumgartner, K., and Cantu, D. 2018. Condition-dependent co-regulation of genomic clusters of virulence factors in the grapevine trunk pathogen Neofusicoccum parvum. Mol. Plant Pathol. 18:21-24.

Mehrabi, M., Hemmati, R., and Abdollahzadeh, J. 2017. Description of the sexual morph of Seimatosporium vitis. Cryptogam. Mycol. 38:3-11.

Morales-Cruz, A., Allenbeck, G., Figueroa-Balderas, R., Ashworth, V. E., Lawrence, D. P., Travadon, R., Smith, R. J., Baumgartner, K., Rolshausen, P. E., and Cantu, D. 2018. Closed-reference metatranscriptomics enables in planta profiling of putative virulence activities in the grapevine trunk disease complex. Mol. Plant Pathol. 19:490-503.

Morales-Cruz, A., Amrine, K. C. H., Blanco-Ulate, B., Lawrence, D. P., Travadon, R., Rolshausen, P. E., Baumgartner, K., and Cantu, D. 2015. Distinctive expansion of gene families associated with plant cell wall degradation, secondary metabolism, and nutrient uptake in the genomes of grapevine trunk pathogens. BMC Genomics 16:469.

Nag Raj, T. R. 1993. Coelomycetous Anamorphs with Appendage-Bearing Conidia. Mycologue Publications, Waterloo, Ontario, Canada.

Nomura, K., Melotto, M., and He, S.-Y. 2005. Suppression of host defense in compatible plant-Pseudomonas syringae interactions. Curr. Opin. Plant Biol. 8:361-368.

Norphanphoun, C., Maharachchikumbura, S. S. N., Daranagama, D. A., Bulgakov, T. S., Bhat, D. J., Bahkali, A. H., and Hyde, K. D. 2015. Towards a backbone tree for Seimatosporium, with S. physocarpi sp. nov. Mycosphere 6:385-400.

O’Donnell, K., and Cigelnik, E. 1997. Two divergent intragenomic rDNA ITS2 types within a monophyletic lineage of the fungus Fusarium are nonorthologous. Mol. Phylogenet. Evol. 7:103-116.

Perera, R. H., Maharachchikumbura, S. S. N., Bahkali, A. H., Camporesi, E., GarethJones, E. B., Phillips, A. J. L., and Hyde, K. D. 2016. Sexual morph of Seimatosporium cornii found on Cornus sanguinea in Italy. Phytotaxa 257:51-60.

Rayner, R. W. 1970. A Mycological Colour Chart. Commonwealth Mycological Institute, Kew, UK.

Rehner, S. A., and Samuels, G. J. 1994. Taxonomy and phylogeny of Gliocladium analysed from nuclear large subunit ribosomal DNA sequences. Mycol. Res. 98:625-634
Senanayake, I. C., Maharachchikumbura, S. S. N., Hyde, K. D., Bhat, J. D. Gareth-Jones, E. B., McKenzie, E. H. C., Dai, D. Q., Daranagama, D. A., Dayarathne, M. C., Goonasekara, I. D., Konta, S., Li, W. J., Shang, Q. J., Stadler, M., Wijayawardene, N. N., Xiao, Y. P., Norphanphoun, C., Li, Q., Liu, X. Z., Bahkali, A. H., Kang, J. C., Wang, Y., Wen, T. C., Wendt, L., $\mathrm{Xu}$, J. C., and Camporesi, E. 2015. Towards unraveling relationships in Xylariomycetidae (Sordariomycetes). Fungal Divers. 73:73-144.

Sergeeva, V., Priest, M., and Nair, N. G. 2005. Species of Pestalotiopsis and related genera occurring on grapevines in Australia. Austral. Plant Pathol. 34: 255-258.

Sipiora M. J., and Cuellar S. 2014. Economic impact of Eutypa dieback. Wine Bus Mon. October:46-49.

Sosnowski, M. R., Lardner, R., Wicks, T. J., and Scott, E. S. 2007. The influence of grapevine cultivar and isolate of Eutypa lata on wood and foliar symptoms. Plant Dis. 91:924-931.

Sutton, B. C. 1980. The Coelomycetes. Fungi Imperfecti with Pycnidia, Acervuli and Stromata. Commonwealth Mycological Institute, Kew, Surrey, England, UK.

Tamura, K., Stecher, G., Peterson, D., Filipski, A., and Kumar, S. 2013. MEGA6: Molecular evolutionary genetics analysis, version 6.0. Mol. Biol. Evol. 30: 2725-2729.

Tanaka, K., Endo, M., Hirayama, K., Okane, I., Hosoya, T., and Sato, T. 2011. Phylogeny of Discosia and Seimatosporium, and introduction of Adisciso and Immersidiscosia genera nova. Persoonia 26:85-98.

Tey-Rulh, P., Philippe, I., Renaud, J.-M., Tsoupras, G., De Angelis, P., Fallot, J., and Tabacchi, R. 1991. Eutypine, a phytotoxin produced by Eutypa lata the causal agent of dying-arm disease of grapevine. Phytochemistry 30:471-473.

Travadon, R., and Baumgartner, K. 2015. Molecular polymorphism and phenotypic diversity in the Eutypa Dieback pathogen Eutypa lata. Phytopathology 105 255-264.

Travadon, R., Lecomte, P., Diarra, B., Lawrence, D. P., Renault, D., Ojeda, H., Rey, P., and Baumgartner, K. 2016. Grapevine pruning systems and cultivars influence the diversity of wood-colonizing fungi. Fungal Ecol. 24:82-93.

Travadon, R., Rolshausen, P. E., Gubler, W. D., Cadle-Davidson, L., and Baumgartner, K. 2013. Susceptibility of cultivated and wild Vitis spp. to wood infection by fungal trunk pathogens. Plant Dis. 97:1529-1536.

Trouillas, F. P., Úrbez-Torres, J. R., and Gubler, W. D. 2010. Diversity of Diatrypaceous fungi associated with grapevine canker diseases in California Mycologia 102:319-336.

Úrbez-Torres, J. R., Adams, P., Kamas, J., and Gubler, W. D. 2009. Identification, incidence, and pathogenicity of fungal species associated with grapevine dieback in Texas. Am. J. Enol. Vitic. 60:497-507.

Úrbez-Torres, J. R., and Gubler, W. D. 2009. Pathogenicity of Botryosphaeriaceae species isolated from grapevine cankers in California. Plant Dis. 93:584-592.

Váczy, K. Z. 2017. First report of Seimatosporium vitis associated with grapevine trunk disease symptoms in Hungary. Plant Dis. 101:253

Watanabe, K. Sekiguchi, M., Sato, T., Hsiang, T., Kaneko, S., Tanaka, K., Kanda, M., Fujita, N., and Nozawa, S. 2016. Phylogenetic analysis of the synnemaproducing genus Synnimapestaloides. J. Fungi 2:28.

White, T. J., Bruns, T., Lee, S., and Taylor, J. 1990. Amplification and direct sequencing of fungal and ribosomal RNA genes for phylogenetics. Pages 315-322 in: PCR Protocols: A Guide to Methods and Applications. M. A. Innis, D. H. Gelfand, J. J. Sninsky, and T. J. White, eds. Academic Press, Inc., San Diego, CA.

Whitelaw-Weckert, M. A., Rahman, L., Appleby, L. M., Hall, A., Clark, A. C. Waite, H., and Hardie, W. J. 2013. Co-infection by Botryosphaeriaceae and Ilyonectria spp. fungi during propagation causes decline of young grafted grapevines. Plant Pathol. 62:1226-1237.

Wijayawardene, N. N., Hyde, K. D., Wanasinghe, D. N., Papizadeh, M. Goonasekara, I. D., Camporesi, E., Bhat, D. J., McKenzie, E. H. C., Phillips, A J. L., Diederich, P., Tanaka, K., Li, W. J., Tangthirasunun, N., Phookamsak, R. Dai, D.-Q., Dissanayake, A. J., Weerakoon, G., Maharachchikumbura, S. S. N., Hashimoto, A., Matsumura, M., Bahkali, A. H., and Wang, Y. 2016. Taxonomy and phylogeny of dematiaceous coelomycetes. Fungal Divers. 77:1-316.

Wilcox, W. F., Ellis, M., Rawnsley, B., Rossman, A. Y., and Pscheidt, J. 2015 Phomopsis Cane and Leaf Spot. Pages 68-71 in: Compendium of Grape Diseases, Disorders, and Pests, 2nd ed. W. F. Wilcox, W. D. Gubler, and J. K. Uyemoto, eds. American Phytopathological Society, St. Paul, MN. 